\title{
The Complement System Component C5a Produces Thermal Hyperalgesia via Macrophage-to-Nociceptor Signaling That Requires NGF and TRPV1
}

\author{
¿ Leonid P. Shutov, ${ }^{1 *}$ @Charles A. Warwick, ${ }^{1 *}$ Xiaoyu Shi, ${ }^{2}$ Aswini Gnanasekaran, ${ }^{1}$ Andrew J. Shepherd, ${ }^{1,3}$ \\ Durga P. Mohapatra, ${ }^{1,3}$ ○Trent M. Woodruff, ${ }^{4}$ J. David Clark, ${ }^{2}$ and Yuriy M. Usachev ${ }^{1}$ \\ ${ }^{1}$ Department of Pharmacology, University of Iowa, Iowa City, Iowa 52242, ${ }^{2}$ Department of Anesthesia, Veterans Administration Palo Alto Healthcare \\ System and Stanford University, Palo Alto, California 94305, ${ }^{3}$ Department of Anesthesiology, Washington University Pain Center, Washington University \\ School of Medicine, St. Louis, Missouri 63110, and ${ }^{4}$ School of Biomedical Sciences, University of Queensland, St. Lucia, Queensland 4072, Australia
}

The complement cascade is a principal component of innate immunity. Recent studies have underscored the importance of C5a and other components of the complement system in inflammatory and neuropathic pain, although the underlying mechanisms are largely unknown. In particular, it is unclear how the complement system communicates with nociceptors and which ion channels and receptors are involved. Here we demonstrate that inflammatory thermal and mechanical hyperalgesia induced by complete Freund's adjuvant was accompanied by $\mathrm{C} 5 \mathrm{a}$ upregulation and was markedly reduced by $\mathrm{C} 5 \mathrm{a}$ receptor $(\mathrm{C} 5 \mathrm{aR} 1)$ knock-out or treatment with the C5aR1 antagonist PMX53. Direct administration of C5a into the mouse hindpaw produced strong thermal hyperalgesia, an effect that was absent in TRPV1 knock-out mice, and was blocked by the TRPV1 antagonist AMG9810. Immunohistochemistry of mouse plantar skin showed prominent expression of $\mathrm{C} 5 \mathrm{aR} 1$ in macrophages. Additionally, $\mathrm{C} 5 \mathrm{a}$ evoked strong $\mathrm{Ca}^{2+}$ mobilization in macrophages. Macrophage depletion in transgenic macrophage Fas-induced apoptosis mice abolished C5a-dependent thermal hyperalgesia. Examination of inflammatory mediators following C5a injection revealed a rapid upregulation of NGF, a mediator known to sensitize TRPV1. Preinjection of an NGFneutralizing antibody or Trk inhibitor GNF-5837 prevented C5a-induced thermal hyperalgesia. Notably, NGF-induced thermal hyperalgesia was unaffected by macrophage depletion. Collectively, these results suggest that complement fragment C5a induces thermal hyperalgesia by triggering macrophage-dependent signaling that involves mobilization of NGF and NGF-dependent sensitization of TRPV1. Our findings highlight the importance of macrophage-to-neuron signaling in pain processing and identify C5a, NGF, and TRPV1 as key players in this cross-cellular communication.

Key words: C5a; C5aR1; complement; macrophage; NGF; TRPV1

\section{Significance Statement}

This study provides mechanistic insight into how the complement system, a key component of innate immunity, regulates the development of pain hypersensitivity. We demonstrate a crucial role of the C5a receptor, C5aR1, in the development of inflammatory thermal and mechanical sensitization. By focusing on the mechanisms of $\mathrm{C} 5 \mathrm{a}$-induced thermal hyperalgesia, we show that this process requires recruitment of macrophages and initiation of macrophage-to-nociceptor signaling. At the molecular level, we demonstrate that this signaling depends on NGF and is mediated by the heat-sensitive nociceptive channel TRPV1. This deeper understanding of how immune cells and neurons interact to regulate pain processing is expected to facilitate mechanism-based approaches in the development of new analgesics.

\section{Introduction}

The complement system is a critical part of innate immunity and plays an important role in the recognition and clearance of patho- gens. It consists of $>30$ soluble and membrane-bound proteins that are rapidly mobilized through a cascade of enzymatic reactions and participate in host defenses through a range of mechanisms, including direct killing of bacteria, facilitation of phagocytosis, the recr- 
uitment and activation of immune cells, vasodilation, and an increase in vascular permeability (Monk et al., 2007; Wagner and Frank, 2010; Ricklin and Lambris, 2013; Holers, 2014). Recent studies have highlighted the importance of the complement cascade in the nervous system, particularly in the regulation of nociceptor function and pain processing (Griffin et al., 2007; Jang et al., 2010; Ren and Dubner, 2010; LaCroixFralish et al., 2011). An upregulation of several components of the complement system in the periphery, DRG, and spinal cord has been implicated in inflammatory and neuropathic pain, whereas inhibition of the complement cascade has been reported to produce analgesic effects in several animal models of chronic pain (Twining et al., 2005; Griffin et al., 2007; Jang et al., 2011; LaCroix-Fralish et al., 2011).

Among the many components of the complement system, $\mathrm{C} 5 \mathrm{a}$ is perhaps best established as a potent regulator of pain processing. C5a is a 74 amino acid polypeptide that is rapidly produced in response to injury or infection by proteolytic cleavage of complement protein $\mathrm{C} 5$. Each of the three major complement activation pathways (i.e., classical, lectin, and alternative) can lead to the generation of C5a that acts via a canonical G-protein coupled receptor, C5aR1 (also known as C5aR or CD88), and possibly another recently characterized receptor, C5aR2 (also known as C5L2 or GPR77), to enhance immune responses and produce many other biological effects (Brennan et al., 2012; Klos et al., 2013; Li et al., 2013; Ricklin and Lambris, 2013; Kemper et al., 2014). Numerous studies suggest the importance of C5a in various chronic pain conditions. Indeed, increased production of $\mathrm{C} 5 \mathrm{a}$ has been reported in several pathological states associated with pain, including rheumatoid arthritis, pancreatitis, inflammatory bowel disease, and surgical trauma (Fosse et al., 1987; Roxvall et al., 1989; Jose et al., 1990; Kiener et al., 1998; Grant et al., 2002; Bhatia, 2005). Upregulation of C5 and C5a has also been shown in the animal models of postsurgical pain and neuropathic pain (Griffin et al., 2007; Jang et al., 2011), whereas direct administration of C5a produced prominent thermal and mechanical sensitization in rodents (Levine et al., 1985; Jang et al., 2010, 2011; Moriconi et al., 2014). Notably, genetic deletion of the C5a precursor, C5, reduced neuropathic pain (Griffin et al., 2007), and C5aR1 knock-out (KO) decreased thermal and mechanical sensitization induced by incision (Liang et al., 2012). Moreover, the administration of C5aR1 antagonists produced analgesic effects in various models of inflammatory and neuropathic pain (Clark et al., 2006; Ting et al., 2008; Jang et al., 2011; Moriconi et al., 2014), highlighting the therapeutic potential of pharmacological targeting of C5a and C5aR1 for chronic pain management.

Despite the growing evidence for the crucial role of $\mathrm{C} 5 \mathrm{a}$ in chronic pain, the mechanisms underlying its pronociceptive actions have not been delineated. In particular, it is unclear how C5a and other complement components signal to nociceptors, and which nociceptive ion channels or receptors they target.

*L.P.S. and C.A.W. contributed equally to this work.

Correspondence should be addressed to Dr. Yuriy M. Usachev, Department of Pharmacology, University of lowa Carver College of Medicine, 2-450 BSB, 51 Newton Road, lowa City, IA 52242. E-mail: yuriy-usachev@uiowa.edu. DOI:10.1523/JNEUROSCI.3249-15.2016

Copyright $\odot 2016$ the authors $\quad 0270-6474 / 16 / 365056-16 \$ 15.00 / 0$
Here, by using genetic and pharmacological tools, we identify transient receptor potential vanilloid 1 (TRPV1) as a key molecular target of C5a-induced signaling that leads to thermal hyperalgesia. We also demonstrate that macrophages are required for C5a-induced thermal hyperalgesia, suggesting that macrophageto-nociceptor communication is involved. Finally, we show that NGF, a well-established modulator of TRPV1, is also required and acts downstream of C5a and upstream of TRPV1 in the proposed signaling cascade.

\section{Materials and Methods}

Animals. All experiments involving the use of mice and the procedures used therein were approved by the University of Iowa Institutional Animal Care and Use Committee and were performed in strict accordance with the National Institutes of Health Guide for the care and use of laboratory animals. Every effort was made to minimize the number of mice used and their suffering. Male C57BL/6J or BALB/C (6-10 weeks of age) mice were housed with food and water ad libitum under a $12 \mathrm{~h} \mathrm{light/dark}$ cycle. C5aR1 KO (\#006845; BALB/C), TRPV1 KO (\#003770; C57BL/6J), macrophage Fas-induced apoptosis (MAFIA) (\#005070; C57BL/6J), and phospholipase C $\beta 2$ (PLC $\beta 2)$ KO (\#018064; C57BL/6J) mice were purchased from The Jackson Laboratory.

Macrophage depletion. For drug-inducible macrophage depletion experiments, we used transgenic MAFIA mice (Burnett et al., 2004). These mice express a drug-inducible suicide gene under the control of the macrophage/monocyte-specific colony-stimulating factor (CSF) 1 receptor $(c-f m s)$ promoter, whose activation by the dimerizing compound AP20187 (Clontech catalog \#635069) triggers Fas-induced apoptosis in macrophages and dendritic cells (Burnett et al., 2004; O'Brien et al., 2012; Cho et al., 2014). MAFIA mice do not seem to be depleted of microglia following systemic administration of AP20187, most likely due to poor penetration of the compound through the blood-brain barrier (Burnett et al., 2004; Wang et al., 2013). Male MAFIA mice were administered either $2 \mathrm{mg} / \mathrm{kg}$ of AP20187 dissolved in vehicle (10\% PEG-400 and 1.7\% Tween 80 in PBS) or vehicle alone on a daily basis via intraperitoneal injection for $5 \mathrm{~d}$. Behavioral testing and immunohistochemistry were performed $6 \mathrm{~d}$ after the first injection of AP20187 or vehicle.

Behavioral testing. Thermal and mechanical sensitivity was measured by Hargreaves test and von Frey filament threshold calculation, respectively, as described previously (Schnizler et al., 2008; Jang et al., 2010; Loo et al., 2012; Mickle et al., 2015b). Briefly, mice were acclimatized to the behavioral testing chambers for $2 \mathrm{~h}$ per day beginning $3 \mathrm{~d}$ before testing. The Hargreaves testing apparatus was an IITC Plantar Analgesia Meter (IITC Life Sciences) with the glass tabletop heated to a thermo-neutral temperature. Nociceptive thermal sensitivity was measured by focusing a beam of light on the plantar surface of the hindpaw to generate heat. The time required for the stimulus to elicit withdrawal of the hindpaw (paw withdrawal latency) was recorded using the programmable digital timer 

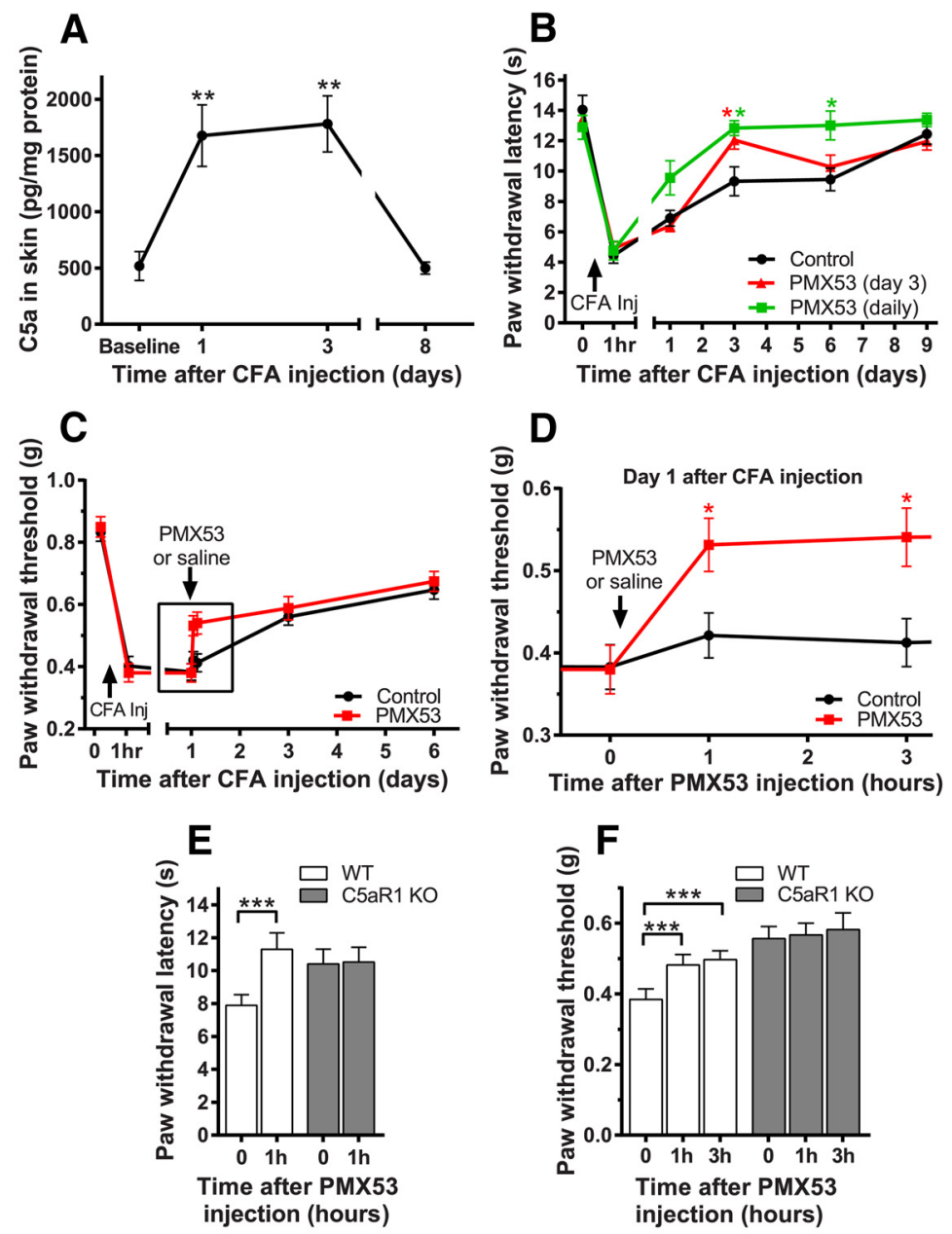

Figure 2. C5aR1 significantly contributes to thermal and mechanical hyperalgesia induced by CFA. $A$, Levels of C5a in skin tissue from naive wild-type C57BL/6J mice (baseline) or after injection of CFA were measured by ELISA at the indicated time points $(n=5$ or 6 mice/time point). ${ }^{* *} p<0.01$, relative to baseline (one-way ANOVA with Bonferroni's post hoc test). $\boldsymbol{B}$, (FA-induced thermal hyperalgesia was compared between three groups of $[57 \mathrm{BL} / 6 \mathrm{~J}$ wild-type mice. The first group received daily administration of vehicle control (black circles; $n=8$ ), the second group received daily administration of the C5aR1 antagonist PMX53 (red triangles; $n=7$ ), and the third group received a single injection of PMX53 ( $1 \mathrm{~h}$ before testing) on day 3 after (FA injection (green squares; $n=8$ ). ${ }^{*} p<0.05$, relative to control (two-way repeated-measures ANOVA with Bonferroni's post hoc test). Green and red asterisks indicate PMX53 (daily) and PMX53 (day 3) mouse groups, respectively. C, D, CFA-induced mechanical hyperalgesia is significantly reduced after administration of PMX53. CFA was injected into the plantar surface of wild-type (C57BL/6J) mice; and then $1 \mathrm{~d}$ after CFA injection, either a saline control $(n=10)$ or PMX53 ( $n=11)$ was administered. After CFA, day 1 was chosen based on the C5aR1 KO findings (Fig. 1B) as the time at which CFA-induced mechanical sensitization was most significantly reduced in C5aR1 KO compared with wild-type mice. Paw withdrawal thresholds were measured either before or 1 and $3 \mathrm{~h}$ after PMX53 injection. C, Highlighted area is replotted for clarity in D using an extended time scale. ${ }^{*} p<0.05$, relative to control (two-way repeated-measures ANOVA with Bonferroni's post hoc test). $\boldsymbol{E}$, Thermal hyperalgesia induced by CFA injection was reduced by PMX53 administration $3 \mathrm{~d}$ after CFA injection in wild-type (BALB/C;n=9) but not C5aR1 KO $(n=9)$ mice. Thermal sensitivity was tested on day 3 after CFA immediately before (time $=0 \mathrm{~h}$ ) and $1 \mathrm{~h}$ after PMX administration. $\boldsymbol{F}$, Mechanical hyperalgesia induced by CFA injection was reduced by PMX53 administration $1 \mathrm{~d}$ after CFA injection in wild-type $(\mathrm{BALB} / C ; n=8)$ but not C5aR1 KO $(n=9)$ mice. Mechanical sensitivity was tested on day 1 after (FA immediately prior (time $=0 \mathrm{~h}$ ) and 1 and $3 \mathrm{~h}$ after PMX administration. ${ }^{* * *} p<0.001$, relative to baseline (time $=0 \mathrm{~h} ; \boldsymbol{E}, \boldsymbol{F}$ ) (two-way repeated-measures ANOVA with Bonferroni's post hoc test).

of the IITC Plantar Analgesia Meter. Baseline latency was determined shortly (15-30 $\mathrm{min}$ ) before drug administration, by averaging the results of three tests separated by a $5 \mathrm{~min}$ interval. For the von Frey testing, mechanical sensitivity was assayed by calculating the $50 \%$ response threshold to 5 presentations each of $0.04,0.07,0.16,0.4,0.6,1.0,1.4$, and $2 \mathrm{~g}$ von Frey filaments (Stoelting). After baseline measurements were taken, either $500 \mathrm{ng}$ recombinant mouse C5a in $10 \mu \mathrm{l}$ PBS, 10 ng NGF in $10 \mu \mathrm{l}$ PBS, or $20 \mu \mathrm{l}$ of Complete Freund's adjuvant (CFA) suspension $(1 \mathrm{mg} / \mathrm{ml})$ was injected into the plantar surface of the hindpaw using a 33-gauge needle (26 gauge in the case of CFA) coupled to a Hamilton syringe. NGF neutralizing antibody, IgG (control), or GNF-5837 was administered into the plantar skin of the hindpaw $30 \mathrm{~min}$ before injection of $\mathrm{C} 5 \mathrm{a}$ or NGF. For systemic administration of the C5aR1 antagonist, PMX53 (Woodruff et al., 2002; Proctor et al., 2006; Woodruff et al., 2006), the drug was dissolved in sterile $5 \%$ glucose/water solution and delivered subcutaneously into the skin of the back of mouse at a $3 \mathrm{mg} / \mathrm{kg}$ dose in a $100 \mu \mathrm{l}$ volume $1 \mathrm{~h}$ before behavioral testing. Efficacy of this dose of PMX53 has been extensively validated (Woodruff et al., 2002; Proctor et al., 2006; Jang et al., 2011; Benson et al., 2015). The individual performing the behavioral measurements was blinded to the drug treatment and mouse genotype where applicable.

ELISA measurements. C5a (500 ng in $10 \mu \mathrm{l}$ PBS) was administered subcutaneously into the hindpaw as described above. Mice (C57BL/ $6 \mathrm{~J})$ were killed by cervical dislocation under isoflurane anesthesia at various time points after injection: 0 (control/baseline), 0.5, 1, 2, 3, and $24 \mathrm{~h}$ (4 mice/time point). A sharp scalpel was used to remove a $3 \times 8 \mathrm{~mm}$ area of skin from the plantar surface of the hindpaw; the skin sample was then cut into small pieces using scissors, and then homogenized in buffer containing $1 \times$ Complete Protease Inhibitor Mixture (Roche Applied Science), $100 \mathrm{~mm}$ Tris/ $\mathrm{HCl}, 1 \mathrm{~m} \mathrm{NaCl}, 4 \mathrm{~mm}$ EDTA, 2\% Triton $\mathrm{X}-100,0.1 \%$ sodium azide using a Polytron homogenizer device. Homogenates were then centrifuged at $12,000 \times g$ for $15 \mathrm{~min}$ at $4^{\circ} \mathrm{C}$, and the supernatant was collected and used to perform a Pierce BCA total protein assay (Thermo Scientific) as described by the manufacturer. Samples were then frozen at $-80^{\circ} \mathrm{C}$ until used for ELISA. NGF and prostaglandin $\mathrm{E}_{2}\left(\mathrm{PGE}_{2}\right)$ measurements were performed using NGF (MD Millipore) and $\mathrm{PGE}_{2}$ (Cayman Chemical) ELISA kits, respectively, according to the manufacturer's recommendations. Multiplex ELISA was performed using the Stanford Human Immune Monitoring Core 26-plex (Stanford University, Palo Alto, CA) and tested for the following cytokines and growth factors: eotaxin (CCL11), granulocyte colony-stimulating factor (G-CSF), granulocyte-monocyte colonystimulating factor (GM-CSF), interferon- $\gamma$ (IFN- $\gamma$ ), IFN- $\gamma$-inducible protein 10 (IP-10/ CXCL10), interleukins IL- $1 \alpha$, IL- $1 \beta$, IL-2, IL-3, IL-4, IL-5, IL-6, IL-10, IL-12-P40, IL-12-P70, IL13, IL-17, and IL-23, keratinocyte-derived chemokine (KC/CXCL1), monocyte chemoattractant protein 1 (MCP-1/CCL2), monocyte chemoattractant protein 3 (MCP-3/CCL7), macrophage inflammatory protein $1 \alpha$ (MIP$1 \alpha /$ CCL3), RANTES (CCL5), tumor necrosis factor $\alpha$ (TNF- $\alpha$ ), transforming growth factor $\beta$ (TGF- $\beta$ ), and vascular endothelial growth factor (VEGF).

For the experiments involving C5a measurements, $20 \mu \mathrm{l} \mathrm{CFA} \mathrm{(1} \mathrm{mg/}$ $\mathrm{ml}$ ) was administered subcutaneously into the hindpaw as described above. Mice (C57BL/6J) were killed by cervical dislocation under isoflurane anesthesia at various time points after injection: 1,3 , and $8 \mathrm{~d}$. Baseline measurements were performed using naive $\mathrm{C} 57 \mathrm{BL} / 6 \mathrm{~J}$ mice. The skin was removed as described above and then frozen at $-80^{\circ} \mathrm{C}$ until used for a C5a ELISA (R\&D Systems) performed according to the manufacturer's recommendations. 
Immunohistochemistry. Immunohistochemical staining and analysis were performed as previously described (Loo et al., 2012; Shepherd and Mohapatra, 2012; Mickle et al., 2015b). In brief, adult male mice were killed and immediately underwent intracardiac perfusion with 4\% PFA in $0.1 \mathrm{~m}$ phosphate buffer (PB). After fixation, $3 \mathrm{~mm}$ plantar punches were taken using a Harris Micro-Punch (Ted Pella), postfixed for $16 \mathrm{~h}$ in $4 \%$ PFA with 5\% picric acid, incubated for $16 \mathrm{~h}$ in decalcification buffer (10\% EDTA, 0.07\% glycerol, and 15\% sucrose in $0.1 \mathrm{M} \mathrm{PB}), 16 \mathrm{~h}$ in cryoprotectant ( $30 \%$ sucrose in $0.1 \mathrm{M} \mathrm{PB}$ ), embedded in Optimal Cutting Temperature (Sakura Finetek), frozen, and sectioned into $40 \mu \mathrm{m}$ sections using a cooled cryostat (CM3050 S; Leica Microsystems). The tissue slices were blocked for $1 \mathrm{~h}$ with blocking buffer containing either 10\% goat (Sigma) or donkey serum (The Jackson Laboratory) and $0.3 \%$ Triton X-100 in $0.1 \mathrm{M}$ $\mathrm{PB}$. Tissue slices were then incubated with primary antibodies diluted in blocking buffer for $24 \mathrm{~h}$, washed 3 times with blocking buffer, and then incubated with secondary antibodies for $2 \mathrm{~h}$. After staining, the sections were mounted on microscope slides with ProLong Gold (Invitrogen). We used the following primary antibodies: rat anti-C5aR1 (1:500; clone 10/92, catalog \#MCA2456GA AbD Serotec), rat anti-F4/80 (1:500; clone A3-1; catalog \#MCA497GA; AbD Serotec), rabbit anti-IBA1 (1:500; catalog \#019-19741; Wako Chemicals), and guinea pig anti-TRPV1 C terminus (1: 1000; catalog \#GP14100; Neuromics). All of these primary antibodies were described previously (Hume et al., 1984; Imai et al., 1996; Guo et al., 1999; Sasmono et al., 2003; Soruri et al., 2003; Tschernig et al., 2007; Brennan et al., 2015). AlexaFluor-488- and AlexaFluor-555-

conjugated goat or donkey secondary antibodies (Invitrogen) were used at a 1:1000 dilution. Images were captured using an Olympus BX61WI microscope equipped with the Fluoview 300 laser-scanning confocal imaging system and either a $20 \times$ objective (NA 0.75 ; Olympus) or a $60 \times$ oil-immersion objective (NA 1.40; Olympus). For quantification, IBA1stained macrophages were imaged by an investigator blinded to the treatment conditions, and quantified using ImageJ software.

Primary macrophage culture. Primary macrophages were isolated and cultured as described by Ray and Dittel (2010). Fluid thioglycolate medium (4\%) (BD Biosciences) was prepared by boiling until the thioglycolate was dissolved, and then autoclaved. After cooling, $3 \mathrm{ml}$ of $4 \%$ thioglycolate was injected into the peritoneal cavity of C57BL/6J, $\mathrm{BALB} / \mathrm{C}, \mathrm{PLC} \beta 2 \mathrm{KO}$, or C5aR1 KO mice. Six days after injection, the mice were killed, and $5 \mathrm{ml}$ of ice-cold PBS with 3\% FBS was injected into the peritoneal cavity with a $27 \mathrm{G}$ needle. The peritoneum was gently massaged for $1 \mathrm{~min}$ to loosen and detach cells. The fluid was then removed by inserting a $25 \mathrm{G}$ needle into the peritoneum and slowly drawing out the fluid. Another $5 \mathrm{ml}$ of PBS $+3 \%$ FBS was then injected, the peritoneum was again massaged, and the fluid was removed in the same manner. The cells were then spun down at 1500 RPM for $8 \mathrm{~min}$, the supernatant was removed, and the cells were resuspended in Complete Macrophage Medium (ScienCell Research Laboratories). The cells were then plated at 6 different dilutions on poly-D-lysine (Sigma)-coated glass coverslips using $8 \mathrm{~mm}$ cloning cylinders and kept in a $5 \% \mathrm{CO}_{2}$ incubator at $37^{\circ} \mathrm{C}$ for $1 \mathrm{~h}$ before adding additional growth media. The cloning cylinders were removed, the cells were washed with growth media to remove nonadherent cells, and then the appropriate cell density was determined by microscopy as yield of macrophages versus nonadherent cells varies. A density of $\sim 75 \%$ confluency was chosen, and remaining cells were plated at that density. Cells were incubated for $24-48 \mathrm{~h}$ before being used for calcium imaging, immunocytochemistry or RT-PCR.

Transfection of primary macrophages. Macrophages were isolated as described and plated on $100 \mathrm{~mm}$ culture dishes for $24 \mathrm{~h}$. The macrophages were then transfected using a Nucleofector Kit for Mouse Macrophages (catalog \#VAPA-1009; Lonza) according to the manufacturer's protocol. Macrophages are a notoriously difficult to transfect cell type; and after experimentation with different transfection techniques, we found that an Amaxa/Lonza nucleofection-based protocol provided $\sim 35 \%$ transfection efficiency. This was substantially better than the results obtained using Lipofectamine 2000 (ThermoFisher) and magnetofection (Oz Biosciences), which yielded $<2 \%$ efficiency after extensive optimization (data not shown).

For our transfection protocol, cultured primary macrophages were briefly washed with PBS, placed in $3 \mathrm{ml} \mathrm{0.05 \%} \mathrm{trypsin} \mathrm{for} 30 \mathrm{~min}$, gently scraped, diluted with $7 \mathrm{ml}$ growth media, and counted. Cells were made into aliquots of $1.0 \times 10^{6}$ cells/transfection and spun down at $200 \times \mathrm{g}$ for $10 \mathrm{~min}$. The cells were resuspended in $100 \mu \mathrm{l}$ Nucleofector solution + supplement $+3 \mu \mathrm{g}$ of plasmid DNA, transferred to an electroporation cuvette, and then transfected using the Y-001 program of the Amaxa Nucelofector II device (Lonza). Culture media $(600 \mu \mathrm{l})$ was added to the cuvette and then transferred to a microcentrifuge tube with $650 \mu \mathrm{l}$ of media. Cells were then plated on six poly-D-lysine-coated glass coverslips using $8 \mathrm{~mm}$ cloning cylinders $(\sim 210 \mu \mathrm{l}$ per cylinder) and were removed after $1 \mathrm{~h}$ after adding $3 \mathrm{ml}$ of growth media to the 6 -well dish. For each transfection $\left(\sim 10^{6}\right.$ cells/transfection), we used either $1 \mu \mathrm{g}$ of each shRNA construct plus $1 \mu \mathrm{g}$ of pmaxGFP (Lonza) or $2 \mu \mathrm{g}$ pLKO.1 empty vector DNA (GE Dharmacon) plus $1 \mu \mathrm{g}$ of pmaxGFP. A set of shRNA plasmids (in pLKO.1 vector) targeting mouse PLC $\beta 3$ were purchased 


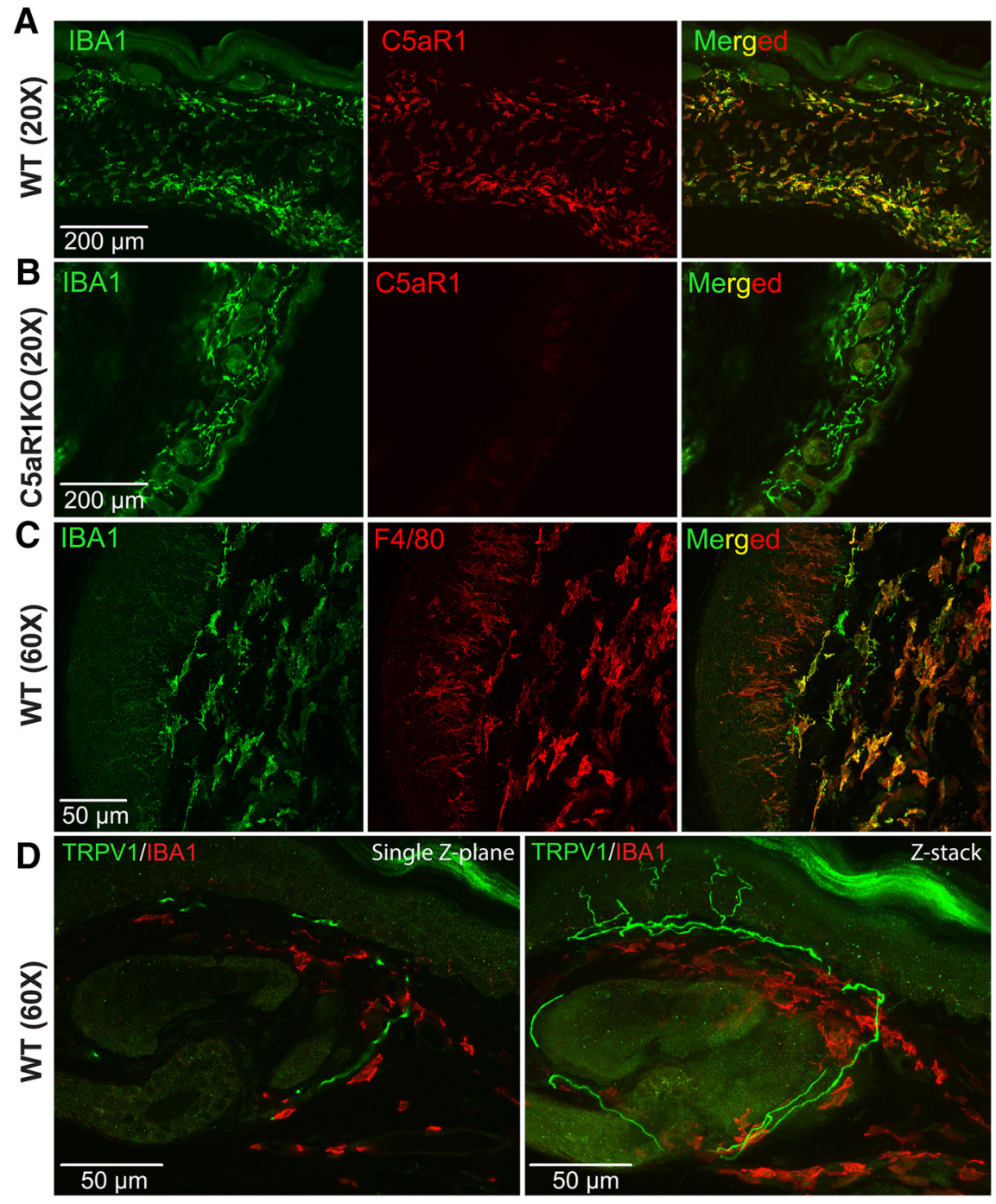

Figure 4. $\quad$ C5aR1 in the skin is expressed primarily in macrophages. Immunohistochemical analysis was performed in skin sections from the mouse hindpaw as described in Materials and Methods, and the images were obtained using either a $20 \times(\boldsymbol{A}, \boldsymbol{B}$; $N A=0.75$; Olympus) or a $60 \times(\boldsymbol{C}, \boldsymbol{D}$; oil-immersion, NA $=1.40$; Olympus) objective. $\boldsymbol{A}, \boldsymbol{B}$, Expression of $(5 \mathrm{aR} 1$ (red) and IBA1 (green; a molecular marker of macrophages) in skin from wild-type $(\boldsymbol{A})$ or C5aR1 KO (B) mice. $\boldsymbol{C}$, Expression of IBA1 (green) and another macrophage marker, F4/80 (red), in the skin. $\boldsymbol{D}$, Expression of TRPV1 (green; primary afferent fibers) and IBA1 (red; macrophages) in the skin. Left, Single Z-plane. Right, Z-stack composite image ( $\Delta Z=15 \mu \mathrm{m}$; Z-step $=0.25 \mu \mathrm{m})$.

from GE Dharmacon (catalog \#RMM4534-EG18797; developed by the Broad Institute's RNAi Consortium/TRC). Using the NIH-3T3 cells, we identified two shRNA plasmids that produced the highest knockdown (see Fig. 6F), shRNA\#1 (ID: TRCN0000076916; 5'-TTTCCAAGGGA AACTCATCAG-3') and shRNA \#2 (ID: TRCN0000076914; 5'-TTT GATGAACTTACTCCCGCG-3'). $\mathrm{Ca}^{2+}$ imaging was performed $48 \mathrm{~h}$ after transfection. Transfected cells were identified by maxGFP fluorescence. The described approach resulted in $\sim 95 \%$ cotransfection as verified by cotransfecting macrophages with mCherry and maxGFP and quantifying cells that coexpress both fluorescent proteins (data not shown).

Calcium imaging. The standard extracellular HEPES-buffered HBSS ( $\mathrm{HH}$ buffer) contained the following (in $\mathrm{mm}$ ): $140 \mathrm{NaCl}, 5 \mathrm{KCl}, 1.3$ $\mathrm{CaCl}_{2}, 0.4 \mathrm{MgSO}_{4}, 0.5 \mathrm{MgCl}_{2}, 0.4 \mathrm{KH} 2 \mathrm{PO}_{4}, 0.6 \mathrm{NaHPO}_{4}, 3 \mathrm{NaHCO}_{3}, 10$ glucose, and 10 HEPES, pH 7.35 with $\mathrm{NaOH}(310 \mathrm{mOsm} / \mathrm{kg}$ with sucrose). Primary macrophages were incubated for 25 min with $2 \mu \mathrm{M}$ of fura-2 $\mathrm{AM}$ (Invitrogen) at room temperature $\left(22^{\circ} \mathrm{C}\right)$. Cells were placed in a flow-through chamber mounted on the stage of an inverted IX-71 microscope (Olympus) and washed for $10 \mathrm{~min}$ with $\mathrm{HH}$ buffer before the experiment. C5a and other drugs were applied by continuous bath superfusion. Fluorescence was alternately excited at 340 and $380 \mathrm{~nm}$ (12 $\mathrm{nm}$ bandpass) using the Polychrome V monochromator (T.I.L.L. Photonics) and a $20 \times$ objective (NA 0.75; Olympus). Emitted fluorescence was collected at $510 \mathrm{~nm}(84 \mathrm{~nm}$ bandpass) using an IMAGO CCD camera (T.I.L.L. Photonics). Pairs of 340/380 nm images were sampled at $1 \mathrm{~Hz}$. The fluorescence ratio $\left(r=\mathrm{F}_{340} / \mathrm{F}_{380}\right)$ was converted to $\left[\mathrm{Ca}^{2+}\right]_{\mathrm{i}}$ according to the formula $\left[\mathrm{Ca}^{2+}\right]_{\mathrm{i}}=K_{\mathrm{d}} \beta(\mathrm{R}-$ $\left.\mathrm{R}_{\min }\right) /\left(\mathrm{R}_{\max }-\mathrm{R}\right)$ (Grynkiewicz et al., 1985). The dissociation constant $\left(K_{\mathrm{d}}\right)$ used for fura-2 was $275 \mathrm{~nm}$ (Shuttleworth and Thompson, 1991). $R_{\min }, R_{\max }$, and $\beta$ were determined by applying $10 \mu \mathrm{m}$ ionomycin in either $\mathrm{Ca}^{2+}$-free buffer (with 1 mM EGTA) or HH buffer $\left(1.3 \mathrm{mM} \mathrm{Ca}^{2+}\right)$. Calibration constants were as follows: $\mathrm{R}_{\min }=0.22, \mathrm{R}_{\max }=3.07$, and $\beta=$ 6.05 . Fluorescence was corrected for background, as determined by an area that did not contain a cell. Data were processed using TILLvisION (T.I.L.L. Photonics) and the GraphPad Prism 6 software, and are presented as mean \pm SEM

Immunocytochemistry. Cells were washed with PBS and then fixed with $4 \%$ PFA for 15-20 min at room temperature. Cells were then washed 3 times with PBS for $5 \mathrm{~min} /$ wash, incubated for $30 \mathrm{~min}$ in blocking buffer $(5 \%$ goat serum and $0.1 \%$ Triton $\mathrm{X}-100$ in PBS), and incubated with rat anti-C5aR1 (1:500; clone 10/92, AbD Serotec) and rabbit antiIBA1 (1:500; Wako Chemicals). The cells were washed 3 times with blocking buffer and then incubated with AlexaFluor-488 goat anti-rat and AlexaFluor-555 goat anti-rabbit secondary antibodies (1:1000; Invitrogen) in blocking buffer at room temperature and in darkness for $30 \mathrm{~min}$. Cells were washed with PBS 3 times and then mounted on a slide using anti-fade reagent Fluoromount-G (Southern Biotechnology). Images were captured using an Olympus BX61WI microscope equipped with the Fluoview 300 laser-scanning confocal imaging system and a $60 \times$ oil-immersion objective (NA 1.40, Olympus) as previously described (Schnizler et al., 2008).

Western blotting. Cells were collected in homogenization buffer $(100 \mathrm{~mm} \mathrm{NaCl}, 50 \mathrm{~mm}$

Tris/ $\mathrm{HCl}, 0.1 \mathrm{~mm}$ EDTA, and $1 \%$ Triton $\mathrm{X}-100$ ) containing a protease inhibitor mixture (Sigma, 1:50) and a phosphatase inhibitor (Sigma, 1:100) and homogenized with a 25-gauge needle. Cell lysates were then diluted with Laemmli reducing buffer and heated at $95^{\circ} \mathrm{C}$ for $5 \mathrm{~min}$ before loading $20 \mu \mathrm{g}$ of protein/sample into an $8 \%$ SDS-polyacrylamide gel. Proteins in SDS-PAGE gels were transferred to nitrocellulose membranes (Bio-Rad) using the transfer buffer $(1.5 \mathrm{~g}$ Tris- $\mathrm{HCl}, 7.2 \mathrm{~g}$ glycine, and $150 \mathrm{ml} \mathrm{MeOH}$ dissolved in $1000 \mathrm{ml} \mathrm{H}_{2} \mathrm{O}$ ). Then, the membrane was incubated with a blocking solution composed of $5 \%$ skim milk in TBS (20 mM Tris- $\mathrm{HCl}, \mathrm{pH} 7.5$, and $150 \mathrm{~mm} \mathrm{NaCl}$ ) for $1 \mathrm{~h}$, washed briefly with TBS, and then incubated with primary antibodies for $4 \mathrm{~h}$. The following primary antibodies were used: rabbit antiPLC 32 (1:500; catalog \#sc-206; Santa Cruz Biotechnology) and rabbit anti-PLC $\beta 3$ (1:500; catalog \#sc-403 Santa Cruz Biotechnology). Both antibodies were extensively described and validated (Ali et al., 1997; Tordjmann et al., 1998; Runnels et al., 2002; Galeotti et al., 2006). GRP75 was used as a loading control and probed with a monoclonal anti-GRP75 antibody (1:2000; clone N52A/42; Neuromab). The membranes were then washed with TBS and incubated either with HRP-conjugated goat anti-rabbit antibodies (1:1000; catalog \#A0545, Sigma) or with HRPconjugated goat anti-mouse antibodies (1:2000; catalog \#48-146-H; An- 
A
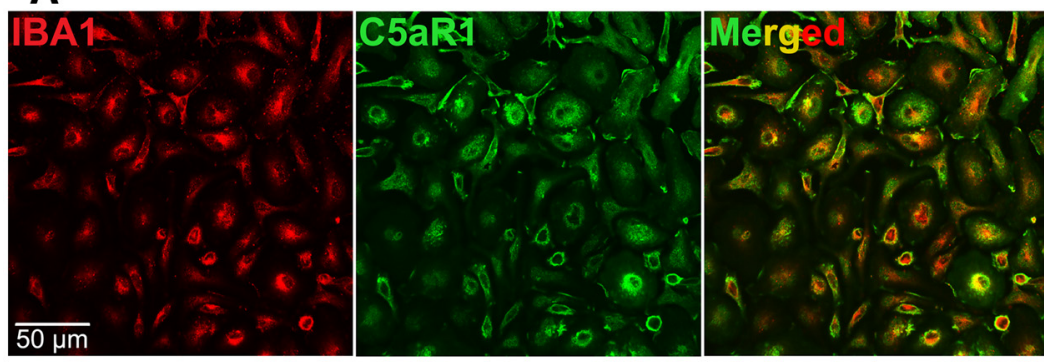

C

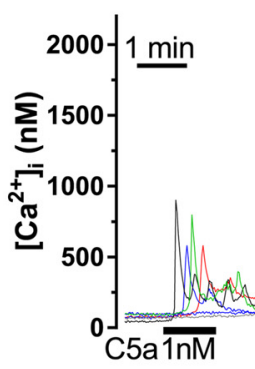

F

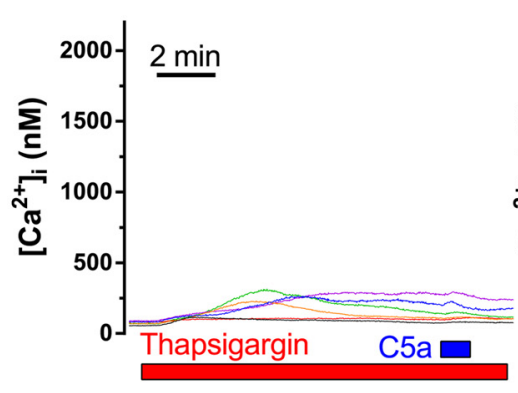

D

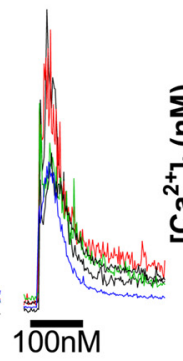

G

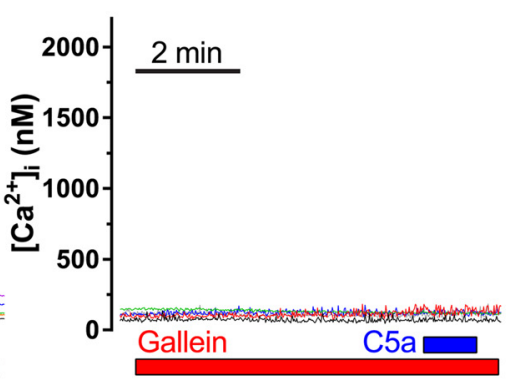

B

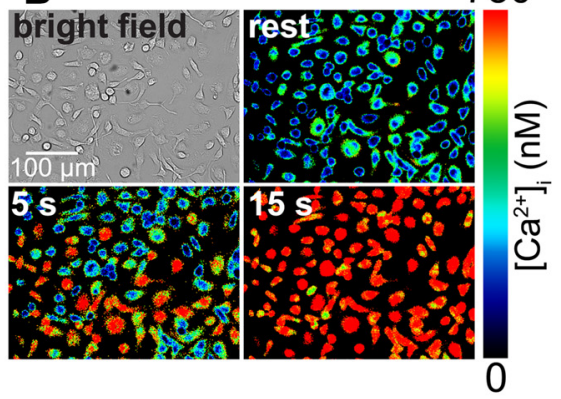

E

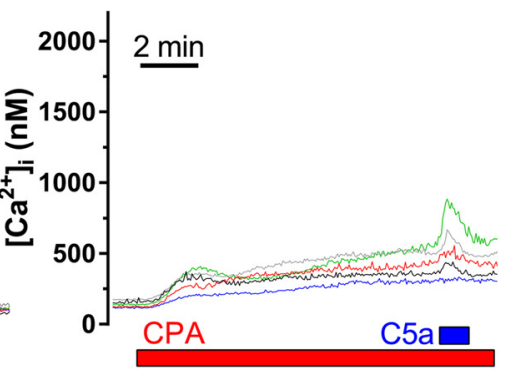

H

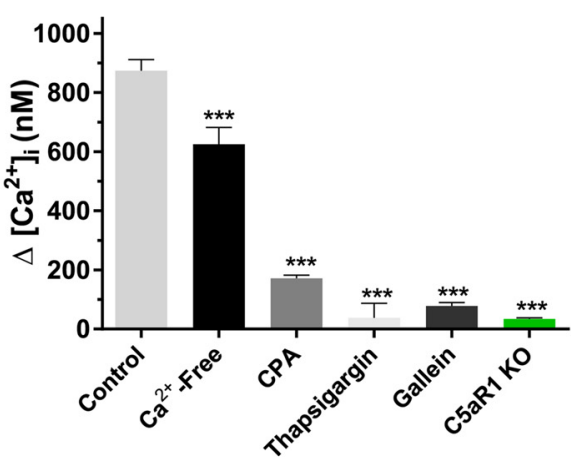

Figure 5. C5a produces a strong $\left[\mathrm{Ca}^{2+}\right]_{\mathrm{i}}$ response in macrophages. $\boldsymbol{A}$, Immunostaining in mouse primary macrophages shows coexpression of IBA1 (red) and C5aR1 (green). B, Bright-field image and three images color-coded for $\left[\mathrm{Ca}^{2+}\right]_{\mathrm{i}}$ represent the same field of mouse primary macrophages loaded with fura-2. The color-coded images show the distribution of $\left[\mathrm{Ca}^{2+}\right]_{\mathrm{i}}$ in macrophages at rest, and at 5 and $15 \mathrm{~s}$ after $100 \mathrm{~nm} \mathrm{C5a}$ was applied. $\mathrm{C}$, Concentration dependence of $\left[\mathrm{Ca}^{2+}\right]_{\mathrm{i}}$ responses to $\mathrm{C5a}$ in macrophages. $\left[\mathrm{Ca}^{2+}\right]_{\mathrm{i}}$ recording was performed simultaneously from several individual macrophages (each cell represented by a different color) in response to 1,10 , or $100 \mathrm{~nm} \mathrm{C5a} \mathrm{applied} \mathrm{for} 1 \mathrm{~min}$. The $\left[\mathrm{Ca}^{2+}\right]_{\mathrm{i}}$ responses to each concentration of C5a were recorded using different coverslips with macrophages. $\boldsymbol{D}-\mathbf{G}$, Representative $\left[\mathrm{Ca}^{2+}\right]_{\mathrm{i}}$ recordings demonstrating the effects of $\mathrm{Ca}^{2+}$-free extracellular buffer (supplied with $0.1 \mathrm{~mm}$ EGTA) (D), SERCA inhibitor cyclopiazonic acid $(10 \mu \mathrm{m} ; \boldsymbol{E})$, structurally distinct SERCA inhibitor thapsigargin $(1 \mu \mathrm{m} ; \boldsymbol{F})$, and $\mathrm{G} \beta$ yinhibitor gallein $(10 \mu \mathrm{m} ; \boldsymbol{G})$ on $\left[\mathrm{Ca}^{2+}\right]_{\mathrm{i}}$ elevations induced by $10 \mathrm{~nm}(5 \mathrm{a}$ ( $1 \mathrm{~min})$ in macrophages. $\boldsymbol{H}$, Bar graph summarizes the effects of $\mathrm{Ca}^{2+}$-free extracellular solution, cyclopiazonic acid, thapsigargin, galleon, and $\mathrm{C5aR} \mathrm{KO}$ on the amplitude of $\left[\mathrm{Ca}^{2+}\right]_{\mathrm{i}}$ responses in macrophages evoked by C5a application (10 nm, $1 \mathrm{~min}) .{ }^{* * *} p<0.001$, relative to control (one-way ANOVA with Bonferroni's post hoc test) ( $n=54-170$ cells). Primary macrophages for immunostaining and all of the $\left[\mathrm{Ca}^{2+}\right]_{\mathrm{i}}$ recordings were obtained from wild-type (57BL/6J mice, except those obtained from C5aR1 K0 mice (H, green bar; BALB/C background). The amplitude of C5a-induced (10 nm, 1 min) $\left[\mathrm{Ca}^{2+}\right]_{\mathrm{i}}$ elevations in macrophages from wild-type BALB/C mice (799 $\pm 62 \mathrm{~nm} ; n=25$; data not shown) was similar to that in macrophages from wild-type $\mathrm{C} 57 \mathrm{BL} / 6 \mathrm{~J} \mathrm{mice}(891 \pm 29 \mathrm{~nm} ; n=170$; $p=0.21$, unpaired Student's $t$ test).

tibodies). Membranes were then washed and developed with ECL+ HRP detection kit (GE Healthcare). All the experiments were repeated 3-5 times.

$R T-P C R$. Total RNA was isolated from primary mouse macrophages 24-48 h after plating or from mouse (C57BL/6J) hippocampi using the RNase easy Plus Mini Kit (QIAGEN) with added on-column DNase-I digestion according to the manufacturer's recommendations. The purified RNA was then reverse transcribed and amplified using the one-step RT-PCR kit (QIAGEN). The following primer sets were used: GAPDH forward: $5^{\prime}$ ACCACAGTCCATGCCATCAC-3'; GAPDH reverse: 5'-CACCACCCT GTTGCTGTAGCC-3'; NGF forward: 5'-ACAGGCAGAACCGTA CACAG-3'; NGF reverse: 5' -TGACGAAGGTGTGAGTCGTG-3'; C5aR1 forward: 5'-CAGGGACCTTCAGGCATCCATT-3'; C5aR1 reverse: 5' TTTGAGCGTCTTGGTGGAGC-3'. RT-PCRs were performed using a Biometra T3 thermocycler. The No RT control reaction did not have a reverse transcription step and was used as a control for contamination with genomic
DNA. The amplified PCR products were separated by electrophoresis on a $2 \%$ agarose gel and were detected using ethidium bromide.

Reagents. Recombinant mouse C5a, GNF-5837, AMG9810, U73122, U73343, o-3M3FBS, m-3M3FBS, thapsigargin, cyclopiazonic acid, and gallein were purchased from R\&D Systems/Tocris Bioscience. CFA was purchased from Sigma; fura-2 AM was obtained from Invitrogen. NGF neutralizing antibody and IgG control were purchased from Ex $\alpha$ Biologicals (catalog \#L148M and 0G11, respectively). NGF was from AbD Serotec, and AP20187 (B/B homodimerizer) was from Takara/Clontech. PMX53 (AcF-[OPdChaWR]acetate salt) was synthesized as reported previously (March et al., 2004), purified by reversed-phase highperformance liquid chromatography, and fully characterized by mass spectrometry.

Statistical analysis. Data are expressed as mean \pm SEM. The following tests were used for analyzing the data: unpaired Student's $t$ (comparison 

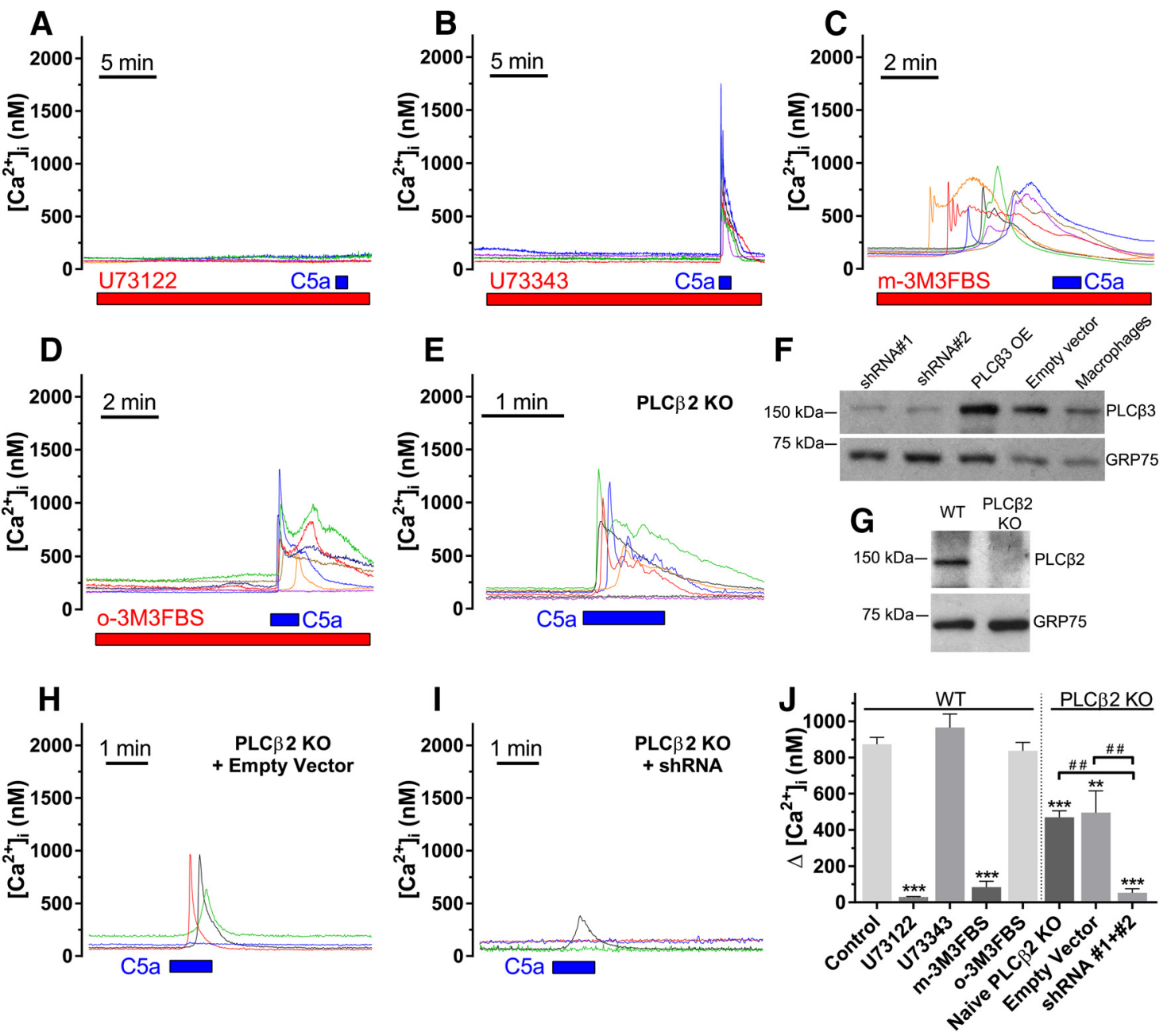

Figure 6. C5a-induced $\left[\mathrm{Ca}^{2+}\right]_{\mathrm{i}}$ elevation in macrophages depends on PLC signaling. $\boldsymbol{A}-\boldsymbol{E}$, Representative $\left[\mathrm{Ca}^{2+}\right]_{\mathrm{i}}$ recordings demonstrate the effects of PLC inhibitor U73122 $(1 \mu \mathrm{M} ; \boldsymbol{A})$, inactive analog of U73122, U73343 (1 $\mu \mathrm{m} ; \boldsymbol{B})$, PLC activator, m-3M3FBS (25 $\mu \mathrm{M} ; \boldsymbol{C}$ ), its inactive variant, 0-3M3FBS (25 $\mu \mathrm{m} ; \boldsymbol{D})$, and PLC $\beta 2$ KO (E) on C5a-induced Ca ${ }^{2+}$ mobilization in macrophages. $\boldsymbol{F}$, Western blot analysis was used to examine expression of PLC $\beta 3$ in wild-type macrophages (lane 5) and NIH-3T3 cells (lanes $1-4$ ) transfected with shRNA against PLC $\beta 3$ (lanes 1 and 2 ), PLC $\beta 3$ (overexpression [OE]; lane 3), or empty vector (pLK0.1; lane 4). GRP75 was used as a loading control. G, Western blot analysis shows expression of PLC $\beta 2$ in wild-type (lane 1), but not in PLC $\beta 2$ KO (lane 2) mice (GRP75 as a loading control). $\boldsymbol{H}, \boldsymbol{I}$, Representative $\left[\mathrm{Ca}^{2+}\right]_{\mathrm{i}}$ recordings were obtained from PLC $\beta 2 \mathrm{KO}$ macrophages transfected either with empty vector (pLK0.1) + maxGFP $(n=16$; $\boldsymbol{H})$ or PLC $\beta 3$ shRNA\#1 + \#2 + maxGFP $(n=13 ; I)$. Transfected macrophages were identified by maxGFP fluorescence. $J$, Bar graph summarizes the effects of U73122, U73343, m-3M3FBS, 0-3M3FBS, PLC $\beta 2 \mathrm{KO}$, empty vector, and PLC $\beta 3$ shRNAs on the amplitude of $\mathrm{C} 5 \mathrm{a}$-induced $\left[\mathrm{Ca}^{2+}\right]_{\mathrm{i}}$ elevations in macrophages. ${ }^{* *} p<0.01$, ${ }^{* * *} p<0.001$, relative to control (wild-type macrophages, $n=170$; replotted from Fig. $5 \mathrm{H}$ ) (one-way ANOVA with Bonferroni's post hoc test). ${ }^{\# \#} p<0.01$, relative to naive PLC $\beta 2 \mathrm{KO}$ macrophages ( $n=13-134$ cells) (one-way ANOVA with Bonferroni's post hoc test).

of 2 groups), one-way ANOVA with Bonferroni's post hoc test (comparison of $>2$ groups), or two-way repeated-measures ANOVA with Bonferroni's post hoc test (time course with comparison of 2 or more groups). A value of $p<0.05$ was considered statistically significant in all cases. Statistical analyses were performed using the GraphPad Prism 6 software.

\section{Results}

C5aR1 significantly contributes to thermal hyperalgesia in the CFA model of inflammatory pain

We first examined the role of C5aR1 in the development and maintenance of inflammatory pain induced by CFA (Stein et al., 1988; Gregory et al., 2013). Intraplantar injection of CFA in wildtype mice produced long-lasting thermal (Fig. $1 A$ ) and mechanical (Fig. 1B) hypersensitivity. CFA-induced thermal hyperalgesia was significantly reduced in $\mathrm{C} 5 \mathrm{aR} 1 \mathrm{KO}$ mice, showing recovery to baseline levels by day 3 after CFA injection (Fig. 1A). C5aR1 KO mice also exhibited a significant reduction in mechanical sensitization (Fig. 1B). Assessment of C5a levels by ELISA revealed a significant and prolonged increase at the site of CFA-induced inflammation, with full recovery by day 8 after injection (Fig. 2A). We also examined the effects of the C5aR1 antagonist PMX53 on CFA-induced thermal hyperalgesia (Woodruff et al., 2002, 2006; Proctor et al., 2006). As shown in Figure 2B, daily administration of PMX53 to wild-type animals markedly diminished thermal hyperalgesia (green squares) compared with control (vehicle-treated; black circles) animals. Furthermore, acute treatment with PMX53 on day 3 after CFA injection rapidly and reversibly reduced thermal hyperalgesia (Fig. 2B, red triangles). Similarly, PMX53 administration $1 \mathrm{~d}$ after CFA injection significantly reduced mechanical hyperalgesia (Fig. $2 C, D)$. In contrast, administration of PMX53 in C5aR1 KO mice did not affect CFA-induced thermal and mechanical hyperalgesia, which is consistent with the selectivity of PMX53 for C5aR1 under our experimental conditions (Fig. 2E,F). These data suggest that C5aR1 plays a critical role in the development and maintenance of thermal and mechanical hyperalgesia during inflammation. 


\section{C5a-induced thermal hyperalgesia is mediated by TRPV 1}

Next, we aimed to identify mechanisms that are responsible for C5aR1-dependent thermal hyperalgesia. In these experiments, thermal hyperalgesia was produced by intraplantar injection of C5a (Fig. 3) as previously described (Jang et al., 2010, 2011). We first examined a dose dependence of $\mathrm{C} 5 \mathrm{a}$ with intraplantar injection of 0 (sham), 10, 100, 500, or 2500 ng of C5a in wild-type mice (Fig. $3 A$ ). As $500 \mathrm{ng}$ showed no significant difference from $2500 \mathrm{ng}$ and lasted much longer than $100 \mathrm{ng}, 500 \mathrm{ng}$ was chosen as an optimal dose for further experiments. Two receptors for C5a have been identified, C5aR1 and C5aR2 (Monk et al., 2007; Klos et al., 2013; Kemper et al., 2014). We found that C5a-induced thermal hyperalgesia was absent in C5aR1 KO mice (Fig. 3B), suggesting that $\mathrm{C} 5 \mathrm{aR} 1$ is responsible for the effects of C5a injection. This is consistent with a previous report that the C5aR1 antagonist PMX53 blocked C5a-induced thermal hyperalgesia (Jang et al., 2011).

Next, we sought to identify a nociceptive ion channel or receptor that could mediate the hyperalgesic effect of C5a. TRPV1 was chosen as a likely candidate given that it is a polymodal nonselective cation channel that is expressed in primary nociceptors and is activated by noxious heat, acidic $\mathrm{pH}$, and lipid-derived endovanilloids. The channel is also critical for development of inflammatory thermal hyperalgesia (Caterina et al., 1997; Caterina et al., 2000; Davis et al., 2000; Bhave and Gereau, 2004; Immke and Gavva, 2006; Patapoutian et al., 2009; Mickle et al., 2015a). We thus tested its role in the C5a pronociceptive effect using TRPV1 KO mice (Caterina et al., 2000). We observed a small increase in baseline paw withdrawal latency in TRPV1 KO mice (Fig. 3C) consistent with previous reports of mild deficit in heat sensitivity in these animals (Caterina et al., 2000; Vardanyan et al., 2009). More importantly, C5a-induced thermal hyperalgesia was nearly abolished in the TRPV1 KO mice (Fig. 3C,D). Furthermore, coadministration of the TRPV1 antagonist AMG9810 blocked the pronociceptive effect of C5a in wild-type animals (Fig. 3C,D). These data indicate that TRPV1 is a critical effector of the C5a-induced signaling that leads to thermal hyperalgesia.

\section{Macrophages are required for C5a-induced thermal hyperalgesia}

To identify the cell type(s) that mediates the effect of C5a, we examined C5aR1 expression in the glabrous skin of the mouse hindpaw. Using a C5aR1-specific antibody, we found a distinct immunoreactivity in skin sections from wild-type mice, but not in those from C5aR1 KO mice (Fig. 4A,B). The majority of the cells that were immunoreactive for C5aR1 also expressed the macrophage marker IBA1 (Imai et al., 1996; Vega-Avelaira et al., 2009; Kwon et al., 2013). The IBA1-positive cells expressed another macrophage marker, F4/80, confirming that the described cells are macrophages (Davies et al., 2013) (Fig. 4C). These macrophages were found in close proximity to TRPV1-positive fibers that innervate the skin (Fig. $4 D$ ), consistent with a potential role of these cells in activating nociceptive signaling.

We also examined C5aR1 expression in macrophages at a functional level. Intracellular $\mathrm{Ca}^{2+}$ signals control many aspects of macrophage activation and function, including migration and cytokine expression and secretion (Onozaki et al., 1983; Underwood and Riches, 1992; Yamamoto et al., 2008; Fric et al., 2012; Desai and Leitinger, 2014). Therefore, we used $\mathrm{Ca}^{2+}$ imaging in primary mouse macrophages to test their response to C5a. Like macrophages in the skin, the cultured primary macrophages prominently expressed C5aR1 (Fig. 5A). We found that brief application of C5a (1-100 nM, $1 \mathrm{~min})$ produced a dosedependent increase in the intracellular $\mathrm{Ca}^{2+}$ concentration $\left(\left[\mathrm{Ca}^{2+}\right]_{\mathrm{i}}\right)$ in all macrophages (Fig. $5 \mathrm{~B}, \mathrm{C}$ ). This C5a-evoked elevation of $\left[\mathrm{Ca}^{2+}\right]_{\mathrm{i}}$ was absent in macrophages obtained from C5aR1 KO mice, indicating that the effect was mediated by C5aR1. Removing extracellular $\mathrm{Ca}^{2+}$ reduced the amplitude of C5a-induced $\left[\mathrm{Ca}^{2+}\right]_{\mathrm{i}}$ response by $\sim 30 \%$ (Fig. $5 D$ ). Depletion of intracellular $\mathrm{Ca}^{2+}$ stores using the inhibitors of the sarcoendoplasmic reticulum $\mathrm{Ca}^{2+}$-ATPase (SERCA), cyclopiazonic acid $(10 \mu \mathrm{M})$, or thapsigargin $(\mathrm{Tg} ; 1 \mu \mathrm{M})$, produced a much stronger effect, diminishing the $\left[\mathrm{Ca}^{2+}\right]_{\mathrm{i}}$ response by $\sim 80 \%$ and $\sim 95 \%$, respectively (Fig. $5 D, E$ ). These findings suggest that intracellular $\mathrm{Ca}^{2+}$ stores are a major source of C5a-induced $\mathrm{Ca}^{2+}$ mobilization in macrophages.

C5aR1 is a Goi-coupled receptor whose activation triggers multiple signaling events, including $\mathrm{G} \beta \gamma$-dependent activation of PLC $\beta$ (Monk et al., 2007; Klos et al., 2013). We focused on the G $\beta \gamma$-PLC signaling pathway because it is well known to lead to the synthesis of inositol 1,4,5-trisphosphate $\left(\mathrm{IP}_{3}\right)$ and $\mathrm{IP}_{3}-$ induced release of $\mathrm{Ca}^{2+}$ from intracellular stores in various cell types (Berridge et al., 2003; Clapham, 2007). We found that the C5a-induced $\left[\mathrm{Ca}^{2+}\right]_{\mathrm{i}}$ increase in macrophages was significantly 

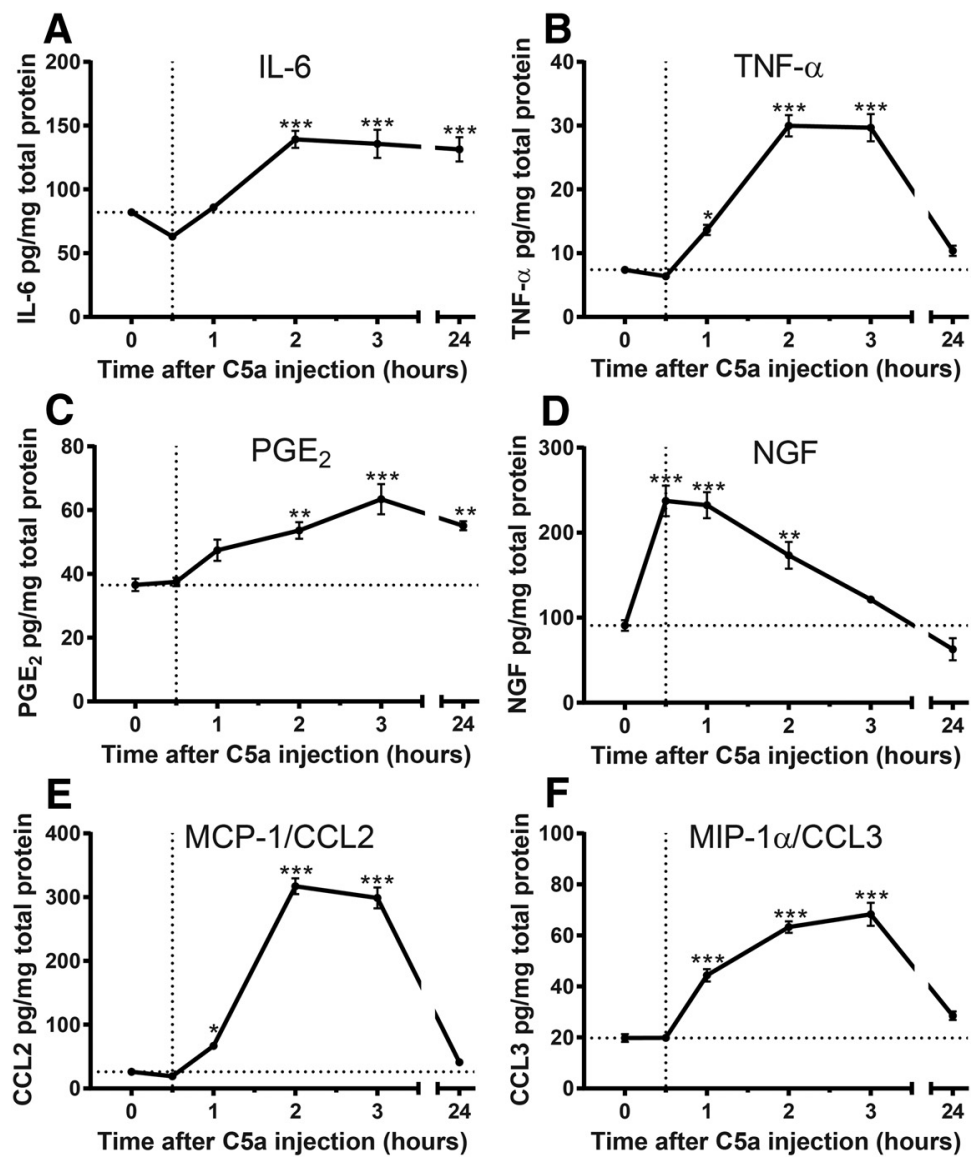

Figure 8. Intraplantar injection of $\mathrm{C} 5 \mathrm{a}$ elevates numerous inflammatory mediators. Time-dependent changes in skin levels of selected inflammatory factors are shown before (time $=0 \mathrm{~h}$ ) and at various time points after C5a injection for IL-6 $(\boldsymbol{A})$, TNF- $\alpha(\boldsymbol{B})$, $\mathrm{PGE}_{2}(\boldsymbol{C}), \mathrm{NGF}(\boldsymbol{D}), \mathrm{MCP}-1 / \mathrm{CCL} 2(\boldsymbol{E})$, and MIP-1 $\alpha / \mathrm{CCL} 3(\boldsymbol{F})$. The complete dataset is shown in Table 1. Horizontal dotted lines indicate the baseline levels for each mediator. Vertical dotted lines indicate the $0.5 \mathrm{~h}$ time point after $\mathrm{C} 5 \mathrm{a}$ injection, at which time thermal hyperalgesia became significant (Figs. 3, 7). Among these mediators, NGF showed the fastest (peak at $0.5 \mathrm{~h}$ ) increase in response to C5a injection. ${ }^{*} p<0.05$, relative to baseline (one-way ANOVA with Bonferroni's post hoc test). ${ }^{* *} p<0.01$, relative to baseline (one-way ANOVA with Bonferroni's post hoc test). ${ }^{* * *} p<0.001$, relative to baseline (one-way ANOVA with Bonferroni's post hoc test). $n=4$ independent experiments/time point.

diminished by application of either the $\mathrm{G} \beta \gamma$ inhibitor gallein (10 $\mu \mathrm{M}$; Fig. $5 G$ ) (Lehmann et al., 2008) or the PLC inhibitor U73122 (1 $\mu$ m; Fig. 6A) (Bleasdale et al., 1990). The inactive analog of U73122, U73343, had no effect on C5a-induced $\left[\mathrm{Ca}^{2+}\right]_{\mathrm{i}}$ elevations ( $1 \mu \mathrm{M}$; Fig. $6 B$ ). Similar to C5a, a selective PLC activator, m-3M3FBS (25 $\mu \mathrm{M}$; Fig. $6 C$ ), but not its inactive analog o-3M3FBS (25 $\mu \mathrm{M}$; Fig. $6 D$ ), produced $\left[\mathrm{Ca}^{2+}\right]_{\mathrm{i}}$ increase in macrophages that was blocked by depleting intracellular $\mathrm{Ca}^{2+}$ stores with $1 \mu \mathrm{M} \mathrm{Tg}$. Indeed, under control conditions, the amplitude of $\mathrm{m}$-3M3FBS-elicited $\left[\mathrm{Ca}^{2+}\right]_{\mathrm{i}}$ elevation was $1043 \pm 90 \mathrm{~nm}(n=$ 45 ), whereas after a pretreatment with $\mathrm{Tg}$ it was diminished to $137 \pm 44 \mathrm{~nm}(n=22 ; p<0.001$, unpaired Student's $t$ test $)$. Furthermore, treatment with m-3M3FBS, but not with o-3M3FBS, prevented a further $\left[\mathrm{Ca}^{2+}\right]_{\mathrm{i}}$ elevation upon C5a application (Fig. $6 C, D$ ), suggesting that $\mathrm{C} 5 \mathrm{a}$ and the PLC activator $\mathrm{m}$-3M3FBS use a common signaling pathway leading to $\left[\mathrm{Ca}^{2+}\right]_{\mathrm{i}}$ increase in macrophages.

Previous studies have reported that the PLC isoforms $\beta 2$ and $\beta 3$ are primarily responsible for C5a-induced signaling in macrophages (Wang et al., 2008; Rebres et al., 2011). Using the PLC $\beta 2$ - and PLC $\beta 3$-specific antibodies, we also found that both PLC isoforms are expressed in macrophages (Fig. $6 F, G$ ). Examination of cultured macrophages from PLC $\beta 2 \mathrm{KO}$ mice showed that the $\mathrm{C} 5 \mathrm{a}$-induced $\left[\mathrm{Ca}^{2+}\right]_{i}$ response in these cells was reduced by $\sim 50 \%$ compared with that in wild-type macrophages (Fig. $6 E, J)$. An additional shRNA-based knockdown of PLC $\beta 3$ in PLC $\beta 2$ KO macrophages virtually eliminated $(\sim 94 \%$ reduction compared with wild-type macrophages) the C5a-induced $\left[\mathrm{Ca}^{2+}\right]_{\mathrm{i}}$ elevation in macrophages (Fig. 6I, J). Collectively, these data suggest that C5a produces a strong $\left[\mathrm{Ca}^{2+}\right]_{\mathrm{i}}$ response in macrophages by triggering $\mathrm{G} \beta \gamma$ - and $\mathrm{PLC} \beta$-dependent $\mathrm{Ca}^{2+}$ release from intracellular (most likely $\mathrm{IP}_{3}$-sensitive) $\mathrm{Ca}^{2+}$ stores, as well as $\mathrm{Ca}^{2+}$ entry via the plasma membrane.

Next, we tested the role of macrophages in C5a-induced thermal hyperalgesia by using the MAFIA mouse, a transgenic model of drug-inducible macrophage ablation (Burnett et al., 2004). These mice express a suicide gene that leads to c-Fas ligand-mediated apoptosis and is controlled by the macrophage/ monocyte-specific promoter $c$-fms (Yue et al., 1993; Sasmono et al., 2003; Burnett et al., 2004). Daily administration of the transgene activator, AP20187, to MAFIA mice for $5 \mathrm{~d}$ decreased macrophage staining (IBA1) in the plantar skin by $85 \%$ relative to vehicle-treated controls (Fig. $7 A-C)$. In vehicle-treated MAFIA mice, intraplantar injection of C5a elicited a rapid and strong thermal hyperalgesia (Fig. 7D, black circles) similar to that observed in wild-type mice (Fig. 3). In contrast, intraplantar injection of C5a produced no changes in thermal sensitivity in the macrophage-depleted MAFIA mice (Fig. $7 D$, red squares). Thus, resident macrophages (and potentially monocytes) are required for the development of C5a-induced thermal hyperalgesia.

NGF plays a critical role in C5a-induced thermal hyperalgesia Based on the data described above, a plausible scenario is that subcutaneously administered C5a acts on macrophages in the skin to trigger macrophage-to-nociceptor signaling that ultimately leads to TRPV1 sensitization and the development of thermal hyperalgesia. To identify signaling molecules that might mediate this cross-cellular communication, we examined how intraplantar injection of $\mathrm{C} 5 \mathrm{a}$ alters the expression profiles of cytokines and other inflammatory mediators in the skin at the site of injection, using a mouse multiplex cytokine analysis kit and ELISA. We found that C5a injection induced a time-dependent upregulation of numerous cytokines, as well as NGF and $\mathrm{PGE}_{2}$ (Fig. 8; Table 1). Given our finding that TRPV1 plays a key role in C5a-induced thermal hyperalgesia, we focused our attention on inflammatory mediators that are known to sensitize this receptor, such as PGE 2 , NGF, IL-6, TNF- $\alpha$, MCP-1 (also known as CCL2), and MIP-1 $\alpha$ (also known as CCL3) (Lopshire and Nicol, 1998; Zhang et al., 2005a, b; White et al., 2007; Constantin et al., 2008; Jung et al., 2008; Khan et al., 2008; Schnizler et al., 2008; Andratsch et al., 2009; Russell et al., 2009). Among these mediators, 
Table 1. C5a-induced changes in the levels of inflammatory mediators in the skin ${ }^{a}$

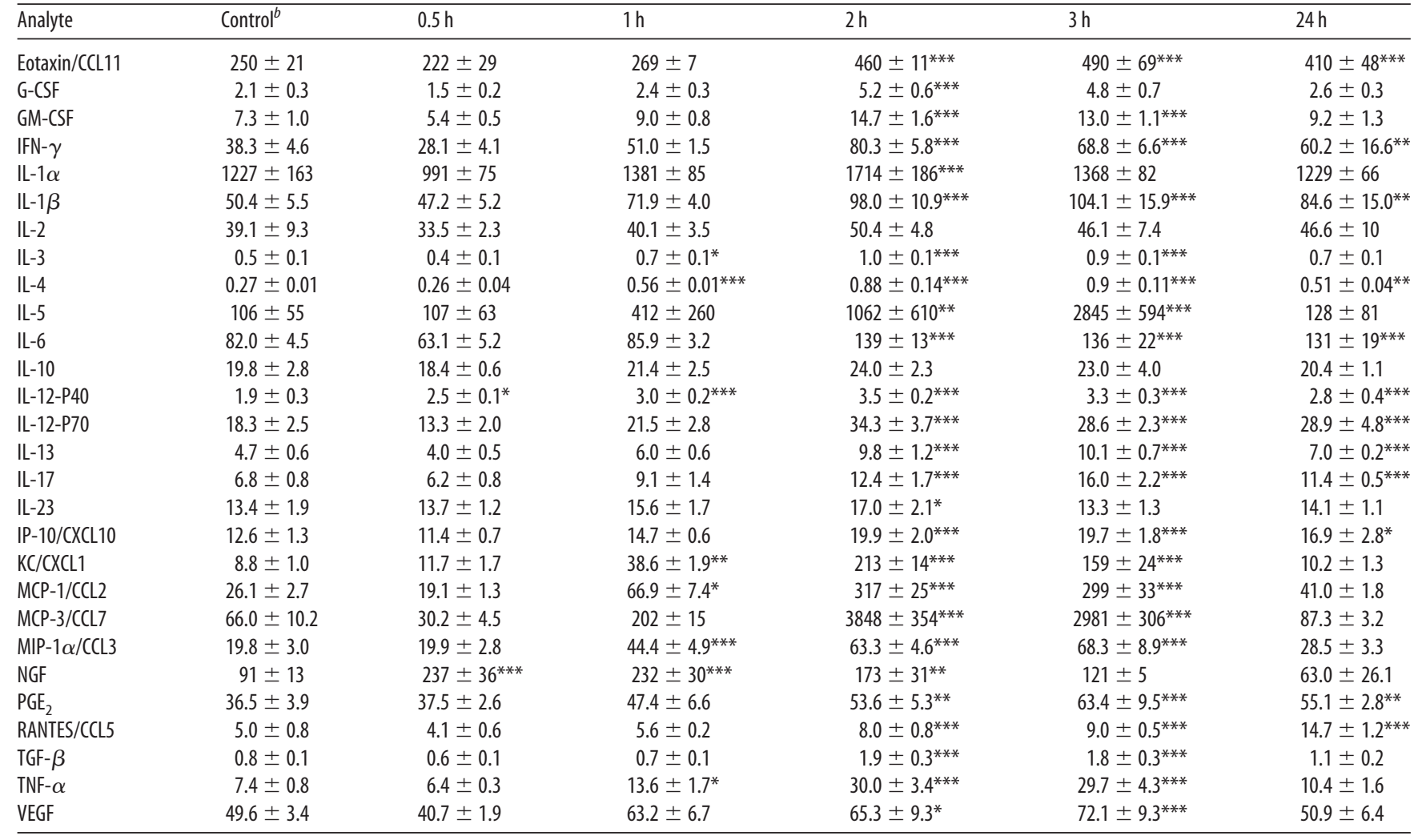

${ }^{a}$ All measurements were made using WT C57BL/6J mice.

${ }^{b}$ Control values are from naive mice. All values are given in $\mathrm{pg}$ analyte/mg total protein as mean \pm SEM.

${ }^{*} p<0.05,{ }^{* *} p<0.01,{ }^{* * *} p<0.001$, relative to control (baseline) values (one-way ANOVA with Bonferroni's post hoc test). $n=4$ independent experiments/time point.

only expression of NGF paralleled the rapid development of C5ainduced thermal hyperalgesia $(30 \mathrm{~min})$ in behavioral testing (Figs. 3, 7). Indeed, NGF levels reached their peak within $30 \mathrm{~min}$ of C5a injection (Fig. 8D). In contrast, all other inflammatory mediators were upregulated at a much slower rate, showing essentially no increase at $30 \mathrm{~min}$ and reaching their peak values within 2-3 $\mathrm{h}$ after $\mathrm{C} 5 \mathrm{a}$ injection (Fig. 8; Table 1 ). Thus, the rapid time course of NGF upregulation combined with the fact that NGF sensitizes TRPV1 through multiple signaling mechanisms (Chuang et al., 2001; Zhang et al., 2005b; Stein et al., 2006; Zhu and Oxford, 2007), and that it is expressed and released by macrophages (Mallat et al., 1989; Garaci et al., 1999; Marcinkiewicz et al., 1999; Obata et al., 2002), makes NGF a likely candidate for mediating the C5a-induced thermal hyperalgesia. Consistent with the latter findings, RT-PCR analysis demonstrated that NGF was expressed in our primary cultures of mouse macrophages (Fig. 9A).

To determine the role of NGF in C5a-induced thermal hyperalgesia, we first examined its effect on thermal sensitivity. We found that intraplantar injection of NGF in wild-type mice induced strong thermal hyperalgesia that lasted for at least $3 \mathrm{~h}$ (Fig. $9 B$ ). As in the case of C5a (Fig. 3), the effect of NGF was absent in TRPV1 KO mice (Fig. 9B). Thus, TRPV1 is a crucial effector of signaling by both C5a and NGF in the context of thermal hyperalgesia. Next, we examined the effects of an NGF-neutralizing antibody (anti-NGF) that had been validated by others (Wild et al., 2007; Cheng et al., 2009; Cheng et al., 2010), and found that it prevented NGF-induced thermal hyperalgesia (data not shown). Moreover, administering anti-NGF, but not a control IgG, 30 min before $\mathrm{C} 5 \mathrm{a}$ administration blocked $\mathrm{C} 5 \mathrm{a}$-induced thermal hyperalgesia (Fig. 9C). This finding validates the critical role of NGF in mediating the hyperalgesic effect of C5a (Fig. 9C). Neither IgG nor anti-NGF treatment affected the baseline (before C5a injection) paw withdrawal latency (Fig. 9C).

NGF is thought to sensitize TRPV1 via the tropomyosinrelated kinase A (TrkA) receptor (Chuang et al., 2001; Zhang et al., 2005b; Zhu and Oxford, 2007). Therefore, we also tested the role of Trk signaling in C5a-induced thermal hyperalgesia. Because of the lack of commercially available isoform-selective Trk inhibitors (Wang et al., 2008; McCarthy and Walker, 2014), we used a potent pan-Trk inhibitor, GNF-5837 (Albaugh et al., 2012), in these experiments. As a positive control, we demonstrated that pretreatment with GNF-5837 inhibited NGF-induced thermal hyperalgesia (Fig. 9D). We found that GNF-5837 inhibited the effect of C5a in a dose-dependent manner (Fig. 9E).

Finally, if NGF functions downstream of macrophage activation in the C5a-induced signaling cascade, its pronociceptive action should theoretically be independent of macrophages. To test this idea, we examined the effect of intraplantar administration of NGF in macrophage-depleted mice. We found that NGF produced a rapid and strong thermal hyperalgesia in macrophage-depleted (AP20187-treated) MAFIA mice and that this effect was similar to that produced by NGF in wild-type mice (Fig. 10). In contrast, C5a administration had no effect in macrophage-depleted mice (Figs. 7, 10).

Together, these data indicate that NGF is required for C5ainduced thermal hyperalgesia and that it acts downstream of macrophage activation and upstream of TRPV1. 
A

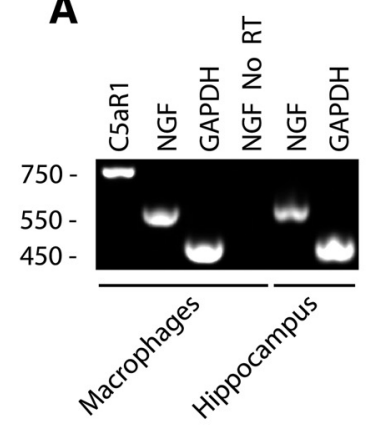

B

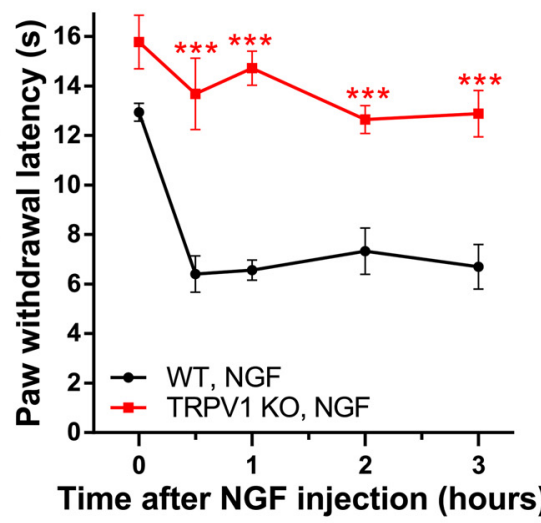

C

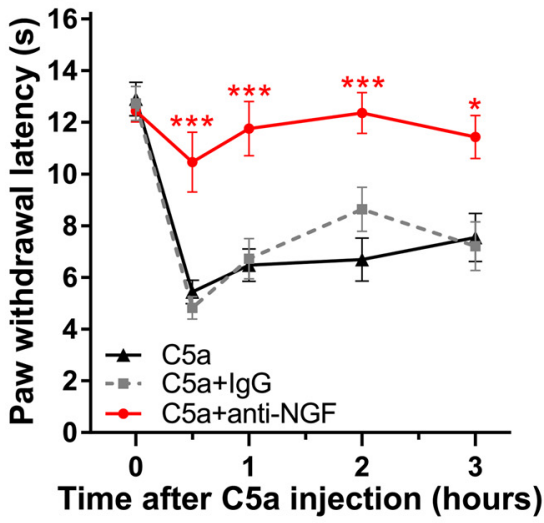

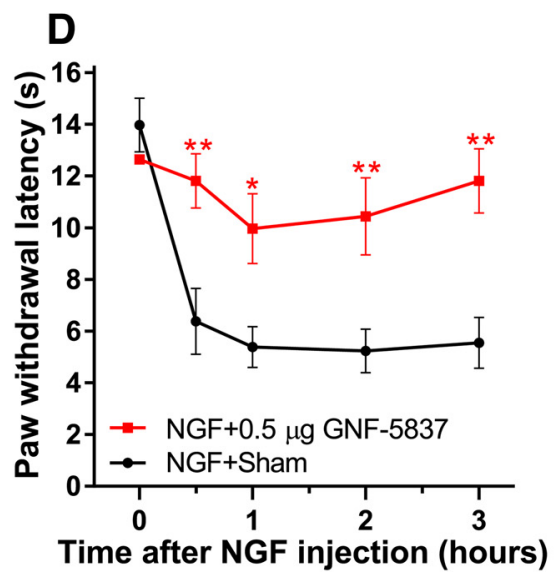

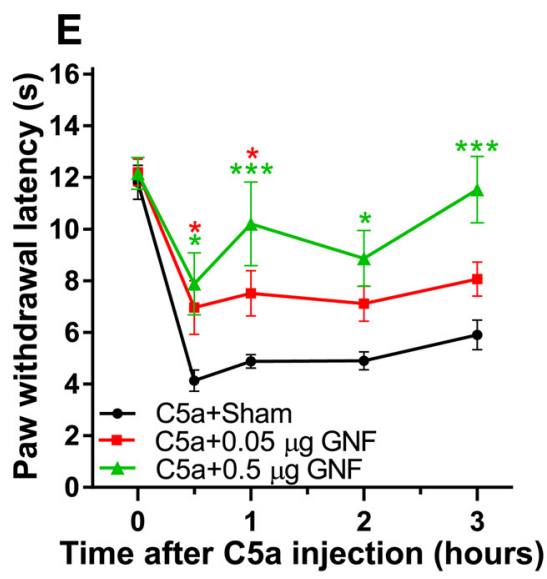

Figure 9. NGF signaling is required for C5a-induced thermal hyperalgesia. A, RT-PCR shows expression of C5aR1 and NGF in primary macrophages (the housekeeping gene GAPDH serves as a control). No RT indicates the negative control reaction for which a reverse transcription step was omitted. Hippocampal mRNA was used as a control for NGF expression (Collins and Crutcher, 1985; Shelton and Reichardt, 1986; Ayer-LeLievre et al., 1988). B, Intraplantar injection of NGF (10 ng) produced thermal hyperalgesia in wild-type (C57BL/6J) mice (black circles; $n=6$ ), but not in TRPV1 K0 mice (red squares; $n=8) .{ }^{* * *} p<0.001$, relative to wild-type (two-way repeated-measures ANOVA with Bonferroni's post hoc test). C, Intraplantar administration of C5a (500 ng) induced thermal hyperalgesia (black triangles; $n=10)$, and this was blocked by pretreatment with the NGF neutralizing antibody ( $1 \mu \mathrm{g} ; 30 \mathrm{~min}$ before C 5 a injection; red circles; $n=16)$, but not by control

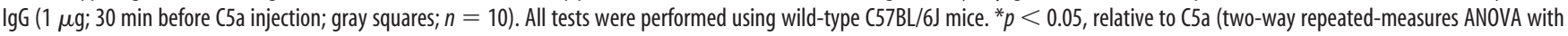
Bonferroni's posthoc test). ${ }^{* * *} p<0.001$, relative to $C 5$ a (two-way repeated-measures ANOVA with Bonferroni's posthoc test). $D$, NGF-induced thermal hyperalgesia (10 ng NGF; black squares; $n=$ 4) was prevented by pretreatment with the Trk inhibitor, GNF-5837 (500 ng; 30 min before NGF injection; red squares; $n=4)$. All tests were performed using wild-type $C 57 \mathrm{BL} / 6 \mathrm{~J}$ mice. ${ }^{*} p<0.05$, relative to NGF + Sham (two-way repeated-measures ANOVA with Bonferroni's post hoc test). ${ }^{* *} p<0.01$, relative to NGF+Sham (two-way repeated-measures ANOVA with Bonferroni's post hoc test). $\boldsymbol{E}$, Thermal hyperalgesia induced by intraplantar Ca ( $500 \mathrm{ng}$; black circles; $n=8)$ was diminished by pretreatment (30 min before C5a injection) with the Trk inhibitor GNF-5837 in a dose-dependent manner ( $50 \mathrm{ng}$, red squares, $n=11 ; 500 \mathrm{ng}$, green triangles, $n=7$ ). All tests were performed using wild-type C57BL/6J mice. ${ }^{*} p<0.05$, relative to C5a + Sham (two-way repeated-measures ANOVA with Bonferroni's post hoc test). ${ }^{* *} p<0.001$, relative to $(5 \mathrm{a}+$ Sham (two-way repeated-measures ANOVA with Bonferroni's post hoc test). Red and green asterisks indicate the 50 and $500 \mathrm{ng}$ doses of GNF-5837, respectively.

\section{Discussion}

In this study, we identify mechanisms that underlie C5a-induced thermal hyperalgesia (Fig. 11). Our findings suggest that C5a generated in response to injury or inflammation acts via macrophages to initiate an intercellular signaling cascade that ultimately causes sensitization of nociceptors to heat. This macrophage-to-nociceptor signaling cascade recruits TRPV1 as a key nociceptive channel that mediates C5a-induced thermal hyperalgesia. In turn, NGF serves as an essential mediator in this cascade that acts downstream of C5aR1 and macrophages, sensitizing TRPV1 to heat via previously identified signaling mechanisms coupled to TrkA activation (Chuang et al., 2001; Zhang et al., 2005b; Zhu and Oxford, 2007). The pathway described here represents a novel signaling module that underlies interactions between the complement system and nociceptive neurons in eliciting pain hypersensitivity (Fig. 11).

There has been growing recognition of the importance of the complement cascade in the nervous system (Brennan et al., 2012;
Stephan et al., 2012). Several of its components contribute to the regulation of neuronal development, synapse plasticity, and remodeling (Stephan et al., 2012). However, excessive activation of the complement system and overproduction of $\mathrm{C} 5 \mathrm{a}$, as well as of $\mathrm{C} 3 \mathrm{a}$, have been linked to neurotoxic processes that occur after stroke, spinal cord injury, and in several chronic neurological disorders, such as multiple sclerosis, amyotrophic lateral sclerosis, and Alzheimer's disease (Veerhuis et al., 2011; Brennan et al., 2012).

The role of the complement system is particularly important in regulating nociceptor function and pain processing ( $\mathrm{Li}$ et al., 2007; Ren and Dubner, 2010). Many components of the complement cascade are upregulated in chronic pain states, and pharmacologic or genetic targeting of the complement system produce analgesic effects (Clark et al., 2006; Levin et al., 2008; Wang et al., 2011; Moriconi et al., 2014). Here, we demonstrated an important role of the complement fragment C5a in the CFA model of inflammatory pain. CFA-induced hyperalgesia was ac- 


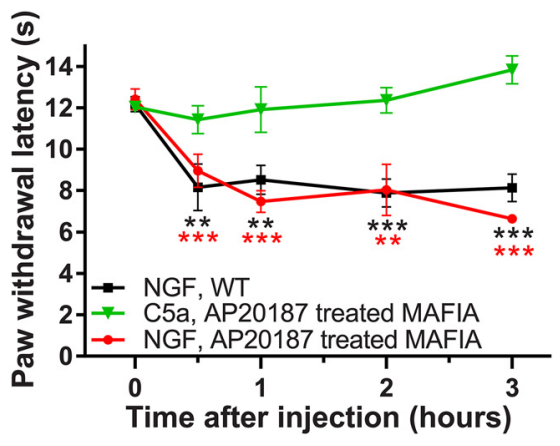

Figure 10. Macrophages are not necessary for NGF-induced thermal hyperalgesia. Heat sensitivity was examined before (baseline time $=0 \mathrm{~h}$ ) and after intraplantar injection of NGF $(10 \mathrm{ng})$ in macrophage-depleted MAFIA mice (red circles; $n=5$ ) and wild-type C57BL/6 J mice (black squares; $n=8$ ). ${ }^{* *} p<0.01$, relative to baseline (two-way repeated-measures ANOVA with Bonferroni's post hoc test). ${ }^{* * *} p<0.001$, relative to baseline (two-way repeatedmeasures ANOVA with Bonferroni's post hoc test). Black and red asterisks indicate wild-type and AP20187-treated MAFIA mice, respectively. Heat sensitivity before and after intraplantar injection of C5a in macrophage-depleted MAFIA mice is shown for comparison (green triangles; $n=8$; replotted from Fig. 7D).

companied by significant upregulation of $\mathrm{C} 5 \mathrm{a}$ in the affected area (Fig. 2A), and both $\mathrm{KO}$ and pharmacological inhibition of C5aR1 markedly diminished CFA-induced thermal and mechanical hyperalgesia, although with a slightly different time dependence (Fig. 1). This difference suggests that $\mathrm{C} 5 \mathrm{a} / \mathrm{C} 5 \mathrm{aR} 1$ play distinct roles during the onset and maintenance of CFA-induced mechanical and thermal sensitization, respectively. Although the doses of C5a required to induce thermal hyperalgesia (Fig. 3) are consistent with the previous work (Jang et al., 2010; Moriconi et al., 2014), they exceed the levels of C5a found in the skin after incision (Jang et al., 2011) or CFA treatment (Fig. 2A) (1-1.7 $\mathrm{ng} / \mathrm{mg}$ protein). However, a number of confounding factors, such as C5a diffusion, its rapid metabolism by serum and cellsurface peptidases, and C5a internalization upon binding to its receptor (Oppermann and Götze, 1994; Monk et al., 2007; Manthey et al., 2009), help to explain why administration of relatively high doses of $\mathrm{C} 5 \mathrm{a}$ is required. Overall, our findings corroborate previous studies that highlight a critical role of $\mathrm{C} 5 \mathrm{a}$ in pain processing (Levine et al., 1985; Clark et al., 2006; Griffin et al., 2007; Jang et al., 2011; Liang et al., 2012; Moriconi et al., 2014).

How does C5a produce a state of pain hypersensitivity? Our results suggest that resident macrophages are the first cells to respond to $\mathrm{C} 5 \mathrm{a}$ elevation in the periphery, and that they are major players in mediating the pronociceptive effects of C5a. First, using the C5aR1 KO-validated antibody, we showed that in skin tissue C5aR1 was present almost exclusively in macrophages (Fig. 4). Second, using $\mathrm{Ca}^{2+}$ imaging, we demonstrated that functional $\mathrm{C} 5 \mathrm{aR} 1$ is expressed in primary macrophages. Specifically, C5aR1 activation was coupled to a robust G $\beta \gamma$ - and PLCdependent $\left[\mathrm{Ca}^{2+}\right]_{\mathrm{i}}$ response (Figs. 5, 6). Third, and most importantly, conditional ablation of macrophages in transgenic mice expressing a suicide gene in macrophages/monocytes abolished C5a-induced hyperalgesia (Fig. 7). It has been previously proposed that the pronociceptive action of C5a depends on neutrophils (Ting et al., 2008). This report relied on systemically administered cytotoxic agent vinblastine to deplete neutrophils. However, this agent is highly toxic to a broad range of cell types in addition toneutrophils and is known to kill many other immune cells, including monocytes and macrophages (Chen and Schooley, 1970; Martin et al., 1981). In contrast, the MAFIA mouse model used in our study allows specific and reversible

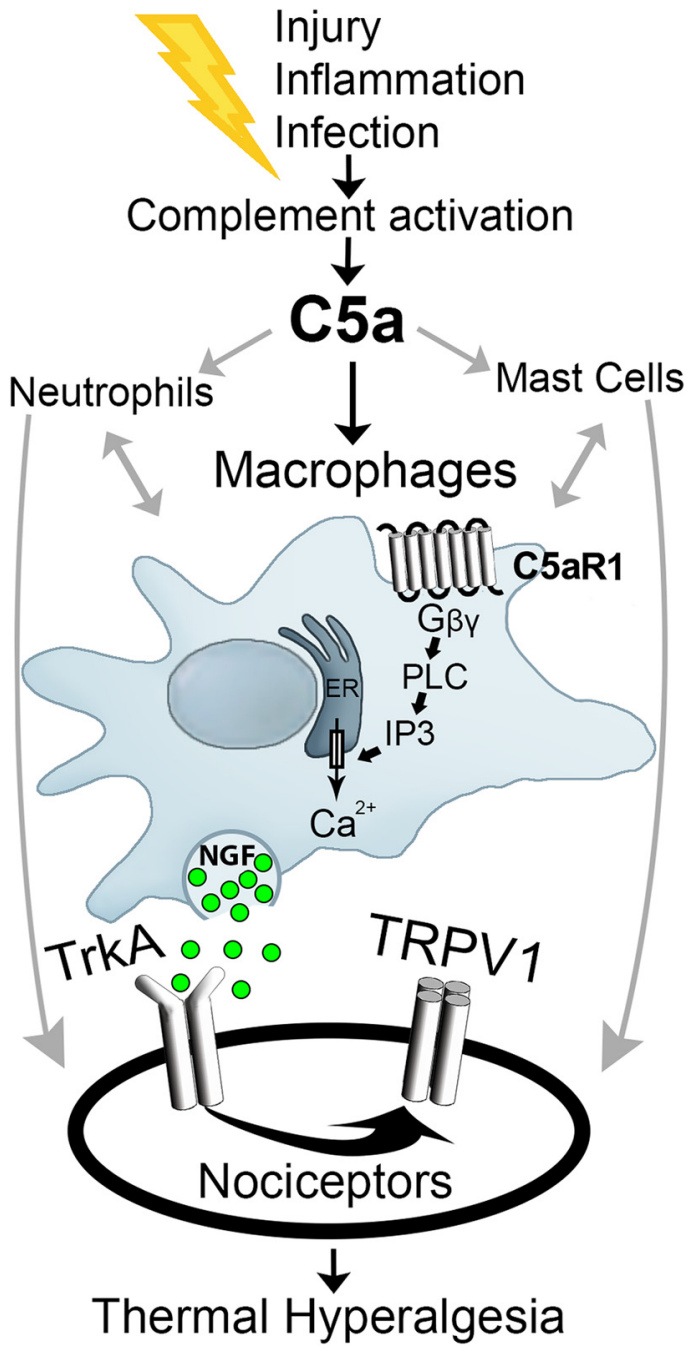

Figure 11. Proposed model describes the signaling pathways activated by C5a in macrophages and nociceptors in the periphery to produce pain hypersensitivity. Activation of the complement cascade in response to injury, infection, or inflammation leads to generation of $C 5 \mathrm{a}$ among other complement products. C5a activates $\mathrm{C} 5 \mathrm{aR} 1$ in macrophages, which triggers $\mathrm{G} \beta \gamma$ and PLC-dependent robust $\mathrm{Ca}^{2+}$ mobilization from intracellular (most likely $\mathrm{IP}_{3}$-sensitive) $\mathrm{Ca}^{2+}$ stores. Although not tested in our work, it has been reported that $\mathrm{C}_{5}$ a induces $\mathrm{IP}_{3}$ synthesis in macrophages (Roach et al., 2008). C5a-induced macrophage activation results in mobilization of NGF and NGF/TrkA-dependent sensitization of TRPV1 in nociceptive fibers to heat. Gray arrows indicate additional signaling pathways and immune cell types (neutrophils and mast cells) that can be affected by $(5 \mathrm{a}$ but were not specifically tested in our work.

elimination of monocytes and monocyte-derived cells (e.g., macrophages), but not of neutrophils or other immune cells (Burnett et al., 2004; Lindauer et al., 2009; Cho et al., 2014). By treating MAFIA mice with the dimerizing compound AP20187, we achieved $\sim 85 \%$ depletion of resident skin macrophages (Fig. 7). Macrophage-depleted mice displayed normal baseline sensitivity to noxious heat (Fig. 7D) and developed strong NGF-induced thermal hyperalgesia (Fig. 10), suggesting that the described treatment did not impair the ability of these mice to sense and respond to noxious heat. Yet, $\mathrm{C} 5 \mathrm{a}$-induced sensitization to heat was eliminated by macrophage ablation. Combined with the observation that subcutaneous C5aR1 is expressed primarily in macrophages, these findings imply that macrophages are essential for C5a-induced thermal hyperalgesia. Future studies will determine whether macrophages also play a crucial role in $\mathrm{C} 5 \mathrm{a}-$ induced mechanical sensitization. 
Macrophages have been implicated in various aspects of inflammatory and neuropathic pain (Sorkin and Schafers, 2007; Ren and Dubner, 2010). They can profoundly affect nociceptor excitability by releasing soluble factors that either activate or sensitize nociceptive neurons. Our findings suggest that NGF serves as a crucial mediator of macrophage-to-nociceptor signaling in the case of C5a-induced thermal hyperalgesia. First, NGF is expressed in macrophages (Figure 9A) (Mallat et al., 1989; Garaci et al., 1999; Marcinkiewicz et al., 1999). Second, out of a broad panel of inflammatory mediators (28 total) tested in our work, only NGF was rapidly upregulated in the affected area in response to $\mathrm{C} 5 \mathrm{a}$, reaching its maximum within $30 \mathrm{~min}$ after the $\mathrm{C} 5 \mathrm{a}$ injection (Fig. 8; Table 1). This time course parallels the rapid development of C5a-induced thermal hyperalgesia (Figs. 3, 7, 9, 10). Other inflammatory mediators monitored in the same assay either reached their peak levels at much later times (2-3 h after C5a injection) or were not affected by C5a (Fig. 8; Table 1). Third, subcutaneously administered NGF mimicked the development of thermal hyperalgesia triggered by $\mathrm{C} 5 \mathrm{a}$, including its critical dependence on TRPV1 (Figs. 3, 7, 9, 10). Thus, C5a and NGF target the same nociceptive channel. Fourth, and most importantly, C5a-induced thermal hyperalgesia was nearly abolished by pretreatment with an NGF-neutralizing antibody (Fig. 9C). Fifth, a Trk inhibitor, GNF-5837, strongly diminished the effect of C5a (Fig. 9E). Finally, NGF-induced thermal hyperalgesia was insensitive to macrophage depletion (Fig. 10), indicating that NGF acts downstream of macrophages in the $\mathrm{C} 5 \mathrm{a}$-induced pronociceptive signaling cascade (Fig. 11).

The finding that NGF serves as a critical mediator of C5a hyperalgesic signaling is consistent with the importance of NGF in many aspects of acute and chronic pain (Stucky et al., 1999; Ji et al., 2002; Pezet and McMahon, 2006). On a long-time scale (days/weeks), NGF contributes to pain hypersensitivity by regulating expression of nociceptive ion channels and neuropeptides, by triggering oxidative mechanisms, and by stimulating aberrant axonal sprouting (Pezet and McMahon, 2006; Mantyh et al., 2011; Eskander et al., 2015). On a short-time scale (seconds/ minutes), NGF sensitizes nociceptors to heat by regulating the surface expression and activation properties of TRPV1 (Chuang et al., 2001; Zhang et al., 2005b). It is likely that NGF-dependent potentiation of TRPV1 is an essential component of the C5ainduced signaling that ultimately leads to heat sensitization described here (Fig. 11). Indeed, TRPV1 was required for the hyperalgesic effects of C5a (Fig. 3), and NGF acted downstream of C5a and upstream of TRPV1 (Fig. 9). Mechanisms underlying the NGF-dependent sensitization of TRPV1 have been well established by others, and hence have not been additionally investigated in our work. They involve activation of the phosphatidylinositol 3-kinase and PLC signaling cascades downstream of TrkA, which facilitates TRPV1 trafficking to the plasma membrane and also sensitizes the receptor to heat, capsaicin, and other activating stimuli (Chuang et al., 2001; Zhang et al., 2005b; Zhu and Oxford, 2007).

Our findings that NGF is required for C5a-induced thermal hyperalgesia do not rule out a potential involvement of other inflammatory mediators upregulated by C5a (Fig. 8; Table 1). Indeed, some of these mediators, such as TNF- $\alpha$, IL- $1 \beta$, IL-6, MCP-1, MIP- $1 \alpha$, and PGE $_{2}$, are known to be secreted by macrophages and to sensitize nociceptive neurons by acting on TRPV1 and other ion channels (Nathan, 1987; Gold et al., 1996; Marchand et al., 2005; Ji et al., 2014). Therefore, it is possible that, in addition to NGF, some of these mediators also contributed to the observed hyperalgesic effects of C5a, although likely at later time points (Fig. 8). Future studies will determine their roles in the pronociceptive effects of C5a.

In conclusion, we have shown that the complement system product $\mathrm{C} 5 \mathrm{a}$ induces a hyperalgesic response by triggering macrophage-to-nociceptor signaling and by recruiting two prominent pain molecules, NGF and TRPV1. Pharmacologic targeting of $\mathrm{C} 5 \mathrm{aR} 1$ may prove to be a useful strategy for treating various chronic pain conditions, including those associated with aberrant activity of NGF and TRPV1.

\section{References}

Albaugh P, Fan Y, Mi Y, Sun F, Adrian F, Li N, Jia Y, Sarkisova Y, Kreusch A, Hood T, Lu M, Liu G, Huang S, Liu Z, Loren J, Tuntland T, Karanewsky DS, Seidel HM, Molteni V (2012) Discovery of GNF-5837, a selective TRK inhibitor with efficacy in rodent cancer models. ACS Med Chem Lett 3:140-145. CrossRef Medline

Ali H, Fisher I, Haribabu B, Richardson RM, Snyderman R (1997) Role of phospholipase Cbeta3 phosphorylation in the desensitization of cellular responses to platelet-activating factor. J Biol Chem 272:11706-11709. CrossRef Medline

Andratsch M, Mair N, Constantin CE, Scherbakov N, Benetti C, Quarta S, Vogl C, Sailer CA, Uceyler N, Brockhaus J, Martini R, Sommer C, Zeilhofer HU, Müller W, Kuner R, Davis JB, Rose-John S, Kress M (2009) A key role for gp130 expressed on peripheral sensory nerves in pathological pain. J Neurosci 29:13473-13483. CrossRef Medline

Ayer-LeLievre C, Olson L, Ebendal T, Seiger A, Persson H (1988) Expression of the beta-nerve growth factor gene in hippocampal neurons. Science 240:1339-1341. CrossRef Medline

Benson MJ, Thomas NK, Talwar S, Hodson MP, Lynch JW, Woodruff TM, Borges K (2015) A novel anticonvulsant mechanism via inhibition of complement receptor C5ar1 in murine epilepsy models. Neurobiol Dis 76:87-97. CrossRef Medline

Berridge MJ, Bootman MD, Roderick HL (2003) Calcium signalling: dynamics, homeostasis and remodelling. Nat Rev Mol Cell Biol 4:517-529. CrossRef Medline

Bhatia M (2005) Inflammatory response on the pancreatic acinar cell injury. Scand J Surg 94:97-102. Medline

Bhave G, Gereau RW 4th (2004) Posttranslational mechanisms of peripheral sensitization. J Neurobiol 61:88-106. CrossRef Medline

Bleasdale JE, Thakur NR, Gremban RS, Bundy GL, Fitzpatrick FA, Smith RJ, Bunting S (1990) Selective inhibition of receptor-coupled phospholipase C-dependent processes in human platelets and polymorphonuclear neutrophils. J Pharmacol Exp Ther 255:756-768. Medline

Brennan FH, Anderson AJ, Taylor SM, WoodruffTM, Ruitenberg MJ (2012) Complement activation in the injured central nervous system: another dual-edged sword? J Neuroinflammation 9:137. CrossRef Medline

Brennan FH, Gordon R, Lao HW, Biggins PJ, Taylor SM, Franklin RJ, Woodruff TM, Ruitenberg MJ (2015) The complement receptor C5aR controls acute inflammation and astrogliosis following spinal cord injury. J Neurosci 35:6517-6531. CrossRef Medline

Burnett SH, Kershen EJ, Zhang J, Zeng L, Straley SC, Kaplan AM, Cohen DA (2004) Conditional macrophage ablation in transgenic mice expressing a Fas-based suicide gene. J Leukoc Biol 75:612-623. CrossRef Medline

Caterina MJ, Schumacher MA, Tominaga M, Rosen TA, Levine JD, Julius D (1997) The capsaicin receptor: a heat-activated ion channel in the pain pathway. Nature 389:816-824. CrossRef Medline

Caterina MJ, Leffler A, Malmberg AB, Martin WJ, Trafton J, Petersen-Zeitz KR, Koltzenburg M, Basbaum AI, Julius D (2000) Impaired nociception and pain sensation in mice lacking the capsaicin receptor. Science 288 : 306-313. CrossRef Medline

Chen MG, Schooley JC (1970) Effects of ionizing radiation and vinblastine on the proliferation of peritoneal macrophage precursors in the mouse. Radiat Res 41:623-636. CrossRef Medline

Cheng HT, Dauch JR, Hayes JM, Hong Y, Feldman EL (2009) Nerve growth factor mediates mechanical allodynia in a mouse model of type 2 diabetes. J Neuropathol Exp Neurol 68:1229-1243. CrossRef Medline

Cheng HT, Dauch JR, Oh SS, Hayes JM, Hong Y, Feldman EL (2010) p38 mediates mechanical allodynia in a mouse model of type 2 diabetes. Mol Pain 6:28. CrossRef Medline

Cho SW, Soki FN, Koh AJ, Eber MR, Entezami P, Park SI, van Rooijen N, 
McCauley LK (2014) Osteal macrophages support physiologic skeletal remodeling and anabolic actions of parathyroid hormone in bone. Proc Natl Acad Sci U S A 111:1545-1550. CrossRef Medline

Chuang HH, Prescott ED, Kong H, Shields S, Jordt SE, Basbaum AI, Chao MV, Julius D (2001) Bradykinin and nerve growth factor release the capsaicin receptor from PtdIns(4,5)P2-mediated inhibition. Nature 411: 957-962. CrossRef Medline

Clapham DE (2007) Calcium signaling. Cell 131:1047-1058. CrossRef Medline

Clark JD, Qiao Y, Li X, Shi X, Angst MS, Yeomans DC (2006) Blockade of the complement $\mathrm{C} 5 \mathrm{a}$ receptor reduces incisional allodynia, edema, and cytokine expression. Anesthesiology 104:1274-1282. CrossRef Medline

Collins F, Crutcher KA (1985) Neurotrophic activity in the adult rat hippocampal formation: regional distribution and increase after septal lesion. J Neurosci 5:2809-2814. Medline

Constantin CE, Mair N, Sailer CA, Andratsch M, Xu ZZ, Blumer MJ, Scherbakov N, Davis JB, Bluethmann H, Ji RR, Kress M (2008) Endogenous tumor necrosis factor alpha (TNFalpha) requires TNF receptor type 2 to generate heat hyperalgesia in a mouse cancer model. J Neurosci 28:50725081. CrossRef Medline

Davies LC, Jenkins SJ, Allen JE, Taylor PR (2013) Tissue-resident macrophages. Nat Immunol 14:986-995. CrossRef Medline

Davis JB, Gray J, Gunthorpe MJ, Hatcher JP, Davey PT, Overend P, Harries MH, Latcham J, Clapham C, Atkinson K, Hughes SA, Rance K, Grau E, Harper AJ, Pugh PL, Rogers DC, Bingham S, Randall A, Sheardown SA (2000) Vanilloid receptor-1 is essential for inflammatory thermal hyperalgesia. Nature 405:183-187. CrossRef Medline

Desai BN, Leitinger N (2014) Purinergic and calcium signaling in macrophage function and plasticity. Front Immunol 5:580. CrossRef Medline

Eskander MA, Ruparel S, Green DP, Chen PB, Por ED, Jeske NA, Gao X, Flores ER, Hargreaves KM (2015) Persistent nociception triggered by nerve growth factor (NGF) is mediated by TRPV1 and oxidative mechanisms. J Neurosci 35:8593-8603. CrossRef Medline

Fosse E, Mollnes TE, Ingvaldsen B (1987) Complement activation during major operations with or without cardiopulmonary bypass. J Thorac Cardiovasc Surg 93:860-866. Medline

Fric J, Zelante T, Wong AY, Mertes A, Yu HB, Ricciardi-Castagnoli P (2012) NFAT control of innate immunity. Blood 120:1380-1389. CrossRef Medline

Galeotti N, Stefano GB, Guarna M, Bianchi E, Ghelardini C (2006) Signaling pathway of morphine induced acute thermal hyperalgesia in mice. Pain 123:294-305. CrossRef Medline

Garaci E, Caroleo MC, Aloe L, Aquaro S, Piacentini M, Costa N, Amendola A, Micera A, Caliò R, Perno CF, Levi-Montalcini R (1999) Nerve growth factor is an autocrine factor essential for the survival of macrophages infected with HIV. Proc Natl Acad Sci U S A 96:14013-14018. CrossRef Medline

Gold MS, Reichling DB, Shuster MJ, Levine JD (1996) Hyperalgesic agents increase a tetrodotoxin-resistant $\mathrm{Na}^{+}$current in nociceptors. Proc Natl Acad Sci U S A 93:1108-1112. CrossRef Medline

Grant EP, Picarella D, Burwell T, Delaney T, Croci A, Avitahl N, Humbles AA, Gutierrez-Ramos JC, Briskin M, Gerard C, Coyle AJ (2002) Essential role for the $\mathrm{C} 5 \mathrm{a}$ receptor in regulating the effector phase of synovial infiltration and joint destruction in experimental arthritis. J Exp Med 196: 1461-1471. CrossRef Medline

Gregory NS, Harris AL, Robinson CR, Dougherty PM, Fuchs PN, Sluka KA (2013) An overview of animal models of pain: disease models and outcome measures. J Pain 14:1255-1269. CrossRef Medline

Griffin RS, Costigan M, Brenner GJ, Ma CH, Scholz J, Moss A, Allchorne AJ, Stahl GL, WoolfCJ (2007) Complement induction in spinal cord microglia results in anaphylatoxin C5a-mediated pain hypersensitivity. J Neurosci 27:8699-8708. CrossRef Medline

Grynkiewicz G, Poenie M, Tsien RY (1985) A new generation of $\mathrm{Ca}^{2+}$ indicators with greatly improved fluorescence properties. J Biol Chem 260: 3440-3450. Medline

Guo A, Vulchanova L, Wang J, Li X, Elde R (1999) Immunocytochemical localization of the vanilloid receptor 1 (VR1): relationship to neuropeptides, the P2X3 purinoceptor and IB4 binding sites. Eur J Neurosci 11: 946-958. CrossRef Medline

Holers VM (2014) Complement and its receptors: new insights into human disease. Annu Rev Immunol 32:433-459. CrossRef Medline

Hume DA, Perry VH, Gordon S (1984) The mononuclear phagocyte system of the mouse defined by immunohistochemical localisation of antigen F4/80: macrophages associated with epithelia. Anat Rec 210:503-512. CrossRef Medline

Imai Y, Ibata I, Ito D, Ohsawa K, Kohsaka S (1996) A novel gene ibal in the major histocompatibility complex class III region encoding an EF hand protein expressed in a monocytic lineage. Biochem Biophys Res Commun 224:855-862. CrossRef Medline

Immke DC, Gavva NR (2006) The TRPV1 receptor and nociception. Semin Cell Dev Biol 17:582-591. CrossRef Medline

Jang JH, Clark JD, Li X, Yorek MS, Usachev YM, Brennan TJ (2010) Nociceptive sensitization by complement C5a and C3a in mouse. Pain 148: 343-352. CrossRef Medline

Jang JH, Liang D, Kido K, Sun Y, Clark DJ, Brennan TJ (2011) Increased local concentration of complement C5a contributes to incisional pain in mice. J Neuroinflammation 8:80. CrossRef Medline

Ji RR, Samad TA, Jin SX, Schmoll R, Woolf CJ (2002) p38 MAPK activation by NGF in primary sensory neurons after inflammation increases TRPV 1 levels and maintains heat hyperalgesia. Neuron 36:57-68. CrossRef Medline

Ji RR, Xu ZZ, Gao YJ (2014) Emerging targets in neuroinflammation-driven chronic pain. Nat Rev Drug Discov 13:533-548. CrossRef Medline

Jose PJ, Moss IK, Maini RN, Williams TJ (1990) Measurement of the chemotactic complement fragment C5a in rheumatoid synovial fluids by radioimmunoassay: role of $\mathrm{C} 5 \mathrm{a}$ in the acute inflammatory phase. Ann Rheum Dis 49:747-752. CrossRef Medline

Jung H, Toth PT, White FA, Miller RJ (2008) Monocyte chemoattractant protein-1 functions as a neuromodulator in dorsal root ganglia neurons. J Neurochem 104:254-263. CrossRef Medline

Kemper C, Pangburn MK, Fishelson Z (2014) Complement nomenclature 2014. Mol Immunol 61:56-58. CrossRef Medline

Khan AA, Diogenes A, Jeske NA, Henry MA, Akopian A, Hargreaves KM (2008) Tumor necrosis factor alpha enhances the sensitivity of rat trigeminal neurons to capsaicin. Neuroscience 155:503-509. CrossRef Medline

Kiener HP, Baghestanian M, Dominkus M, Walchshofer S, Ghannadan M, Willheim M, Sillaber C, Graninger WB, Smolen JS, Valent P (1998) Expression of the C5a receptor (CD88) on synovial mast cells in patients with rheumatoid arthritis. Arthritis Rheum 41:233-245. CrossRef Medline

Klos A, Wende E, Wareham KJ, Monk PN (2013) International Union of Basic and Clinical Pharmacology. [corrected]. LXXXVII. Complement peptide C5a, C4a, and C3a receptors. Pharmacol Rev 65:500-543. CrossRef Medline

Kwon MJ, Kim J, Shin H, Jeong SR, Kang YM, Choi JY, Hwang DH, Kim BG (2013) Contribution of macrophages to enhanced regenerative capacity of dorsal root ganglia sensory neurons by conditioning injury. J Neurosci 33:15095-15108. CrossRef Medline

LaCroix-Fralish ML, Austin JS, Zheng FY, Levitin DJ, Mogil JS (2011) Patterns of pain: meta-analysis of microarray studies of pain. Pain 152: 1888-1898. CrossRef Medline

Lehmann DM, Seneviratne AM, Smrcka AV (2008) Small molecule disruption of $G$ protein beta gamma subunit signaling inhibits neutrophil chemotaxis and inflammation. Mol Pharmacol 73:410-418. Medline

Levin ME, Jin JG, Ji RR, Tong J, Pomonis JD, Lavery DJ, Miller SW, Chiang LW (2008) Complement activation in the peripheral nervous system following the spinal nerve ligation model of neuropathic pain. Pain 137: 182-201. CrossRef Medline

Levine JD, Gooding J, Donatoni P, Borden L, Goetzl EJ (1985) The role of the polymorphonuclear leukocyte in hyperalgesia. J Neurosci 5:30253029. Medline

Li M, Peake PW, Charlesworth JA, Tracey DJ, Moalem-Taylor G (2007) Complement activation contributes to leukocyte recruitment and neuropathic pain following peripheral nerve injury in rats. Eur J Neurosci 26: 3486-3500. CrossRef Medline

Liang DY, Li X, Shi X, Sun Y, Sahbaie P, Li WW, Clark JD (2012) The complement component $\mathrm{C} 5$ a receptor mediates pain and inflammation in a postsurgical pain model. Pain 153:366-372. CrossRef Medline

Li R, Coulthard LG, Wu MC, Taylor SM, Woodruff TM (2013) C5L2: a controversial receptor of complement anaphylatoxin, C5a. FASEB J 27: 855-864. CrossRef Medline

Lindauer ML, Wong J, Iwakura Y, Magun BE (2009) Pulmonary inflamma- 
tion triggered by ricin toxin requires macrophages and IL-1 signaling. J Immunol 183:1419-1426. CrossRef Medline

Loo L, Shepherd AJ, Mickle AD, Lorca RA, Shutov LP, Usachev YM, Mohapatra DP (2012) The C-type natriuretic peptide induces thermal hyperalgesia through a noncanonical Gbetagamma-dependent modulation of TRPV1 channel. J Neurosci 32:11942-11955. CrossRef Medline

Lopshire JC, Nicol GD (1998) The cAMP transduction cascade mediates the prostaglandin E2 enhancement of the capsaicin-elicited current in rat sensory neurons: whole-cell and single-channel studies. J Neurosci 18: 6081-6092. Medline

Mallat M, Houlgatte R, Brachet P, Prochiantz A (1989) Lipopolysaccharidestimulated rat brain macrophages release NGF in vitro. Dev Biol 133: 309-311. CrossRef Medline

Manthey HD, Woodruff TM, Taylor SM, Monk PN (2009) Complement component 5a (C5a). Int J Biochem Cell Biol 41:2114-2117. CrossRef Medline

Mantyh PW, Koltzenburg M, Mendell LM, Tive L, Shelton DL (2011) Antagonism of nerve growth factor-TrkA signaling and the relief of pain. Anesthesiology 115:189-204. CrossRef Medline

March DR, Proctor LM, Stoermer MJ, Sbaglia R, Abbenante G, Reid RC, Woodruff TM, Wadi K, Paczkowski N, Tyndall JD, Taylor SM, Fairlie DP (2004) Potent cyclic antagonists of the complement C5a receptor on human polymorphonuclear leukocytes: relationships between structures and activity. Mol Pharmacol 65:868-879. CrossRef Medline

Marchand F, Perretti M, McMahon SB (2005) Role of the immune system in chronic pain. Nat Rev Neurosci 6:521-532. CrossRef Medline

Marcinkiewicz M, Marcinkiewicz J, Chen A, Leclaire F, Chrétien M, Richardson P (1999) Nerve growth factor and proprotein convertases furin and PC7 in transected sciatic nerves and in nerve segments cultured in conditioned media: their presence in Schwann cells, macrophages, and smooth muscle cells. J Comp Neurol 403:471-485. CrossRef Medline

Martin F, Olsson NO, Jeannin JF (1981) Effects of four agents that modify microtubules and microfilaments (vinblastine, colchicine, lidocaine and cytochalasin B) on macrophage-mediated cytotoxicity to tumor cells. Cancer Immunol Immunother 1981:113-119.

McCarthy C, Walker E (2014) Tropomyosin receptor kinase inhibitors: a patent update 2009-2013. Expert Opin Ther Pat 24:731-744. CrossRef Medline

Mickle AD, Shepherd AJ, Mohapatra DP (2015a) Sensory TRP channels: the key transducers of nociception and pain. Prog Mol Biol Transl Sci 131: 73-118. CrossRef Medline

Mickle AD, Shepherd AJ, Loo L, Mohapatra DP (2015b) Induction of thermal and mechanical hypersensitivity by parathyroid hormone-related peptide through upregulation of TRPV1 function and trafficking. Pain 156:1620-1636. CrossRef Medline

Monk PN, Scola AM, Madala P, Fairlie DP (2007) Function, structure and therapeutic potential of complement C5a receptors. Br J Pharmacol 152: 429-448. CrossRef Medline

Moriconi A, Cunha TM, Souza GR, Lopes AH, Cunha FQ, Carneiro VL, Pinto LG, Brandolini L, Aramini A, Bizzarri C, Bianchini G, Beccari AR, Fanton M, Bruno A, Costantino G, Bertini R, Galliera E, Locati M, Ferreira SH, Teixeira MM, et al. (2014) Targeting the minor pocket of C5aR for the rational design of an oral allosteric inhibitor for inflammatory and neuropathic pain relief. Proc Natl Acad Sci U S A 111:16937-16942. CrossRef Medline

Nathan CF (1987) Secretory products of macrophages. J Clin Invest 79: 319-326. CrossRef Medline

Obata K, Tsujino H, Yamanaka H, Yi D, Fukuoka T, Hashimoto N, Yonenobu K, Yoshikawa H, Noguchi K (2002) Expression of neurotrophic factors in the dorsal root ganglion in a rat model of lumbar disc herniation. Pain 99:121-132. CrossRef Medline

O’Brien J, Martinson H, Durand-Rougely C, Schedin P (2012) Macrophages are crucial for epithelial cell death and adipocyte repopulation during mammary gland involution. Development 139:269-275. CrossRef Medline

Onozaki K, Takenawa T, Homma Y, Hashimoto T (1983) The mechanism of macrophage activation induced by $\mathrm{Ca}^{2+}$ ionophore. Cell Immunol 75:242-254. CrossRef Medline

Oppermann M, Götze O (1994) Plasma clearance of the human C5a anaphylatoxin by binding to leucocyte C5a receptors. Immunology 82 : 516-521. Medline

Patapoutian A, Tate S, Woolf CJ (2009) Transient receptor potential chan- nels: targeting pain at the source. Nat Rev Drug Discov 8:55-68. CrossRef Medline

Pezet S, McMahon SB (2006) Neurotrophins: mediators and modulators of pain. Annu Rev Neurosci 29:507-538. CrossRef Medline

Proctor LM, Woodruff TM, Sharma P, Shiels IA, Taylor SM (2006) Transdermal pharmacology of small molecule cyclic C5a antagonists. Adv Exp Med Biol 586:329-345. CrossRef Medline

Ray A, Dittel BN (2010) Isolation of mouse peritoneal cavity cells. J Vis Exp 35:pii1488. CrossRef Medline

Rebres RA, Roach TI, Fraser ID, Philip F, Moon C, Lin KM, Liu J, Santat L, Cheadle L, Ross EM, Simon MI, Seaman WE (2011) Synergistic $\mathrm{Ca}^{2+}$ responses by G\{alpha\}i- and G\{alpha\}q-coupled G-protein-coupled receptors require a single PLC $\{$ beta $\}$ isoform that is sensitive to both G\{beta\}\{gamma\} and G\{alpha\}q. J Biol Chem 286:942-951. CrossRef Medline

Ren K, Dubner R (2010) Interactions between the immune and nervous systems in pain. Nat Med 16:1267-1276. CrossRef Medline

Ricklin D, Lambris JD (2013) Complement in immune and inflammatory disorders: pathophysiological mechanisms. J Immunol 190:3831-3838. CrossRef Medline

Roach TI, Rebres RA, Fraser ID, Decamp DL, Lin KM, Sternweis PC, Simon MI, Seaman WE (2008) Signaling and cross-talk by C5a and UDP in macrophages selectively use PLCbeta3 to regulate intracellular free calcium. J Biol Chem 283:17351-17361. CrossRef Medline

Roxvall L, Bengtson A, Heideman M (1989) Anaphylatoxin generation in acute pancreatitis. J Surg Res 47:138-143. CrossRef Medline

Runnels LW, Yue L, Clapham DE (2002) The TRPM7 channel is inactivated by PIP(2) hydrolysis. Nat Cell Biol 4:329-336. CrossRef Medline

Russell FA, Fernandes ES, Courade JP, Keeble JE, Brain SD (2009) Tumour necrosis factor alpha mediates transient receptor potential vanilloid 1-dependent bilateral thermal hyperalgesia with distinct peripheral roles of interleukin-1beta, protein kinase $\mathrm{C}$ and cyclooxygenase-2 signalling. Pain 142:264-274. CrossRef Medline

Sasmono RT, Oceandy D, Pollard JW, Tong W, Pavli P, Wainwright BJ, Ostrowski MC, Himes SR, Hume DA (2003) A macrophage colonystimulating factor receptor-green fluorescent protein transgene is expressed throughout the mononuclear phagocyte system of the mouse. Blood 101:1155-1163. CrossRef Medline

Schnizler K, Shutov LP, Van Kanegan MJ, Merrill MA, Nichols B, McKnight GS, Strack S, Hell JW, Usachev YM (2008) Protein kinase A anchoring via AKAP150 is essential for TRPV1 modulation by forskolin and prostaglandin E2 in mouse sensory neurons. J Neurosci 28:4904-4917. CrossRef Medline

Shelton DL, Reichardt LF (1986) Studies on the expression of the beta nerve growth factor (NGF) gene in the central nervous system: level and regional distribution of NGF mRNA suggest that NGF functions as a trophic factor for several distinct populations of neurons. Proc Natl Acad Sci U S A 83:2714-2718. CrossRef Medline

Shepherd AJ, Mohapatra DP (2012) Tissue preparation and immunostaining of mouse sensory nerve fibers innervating skin and limb bones. J Vis Exp 59:e3485. CrossRef Medline

Shuttleworth TJ, Thompson JL (1991) Effect of temperature on receptoractivated changes in $\left[\mathrm{Ca}^{2+}\right] \mathrm{i}$ and their determination using fluorescent probes. J Biol Chem 266:1410-1414. Medline

Sorkin LS, Schafers M (2007) Immune cells in peripheral nerve. In: Immune and glial regulation of pain (DeLeo JA, Sorkin LS, Watkins LR, eds), pp 3-20. Seattle: International Association for the Study of Pain.

Soruri A, Kim S, Kiafard Z, Zwirner J (2003) Characterization of C5aR expression on murine myeloid and lymphoid cells by the use of a novel monoclonal antibody. Immunol Lett 88:47-52. CrossRef Medline

Stein AT, Ufret-Vincenty CA, Hua L, Santana LF, Gordon SE (2006) Phosphoinositide 3-kinase binds to TRPV1 and mediates NGF-stimulated TRPV1 trafficking to the plasma membrane. J Gen Physiol 128:509-522. CrossRef Medline

Stein C, Millan MJ, Herz A (1988) Unilateral inflammation of the hindpaw in rats as a model of prolonged noxious stimulation: alterations in behavior and nociceptive thresholds. Pharmacol Biochem Behav 31:445-451. CrossRef Medline

Stephan AH, Barres BA, Stevens B (2012) The complement system: an unexpected role in synaptic pruning during development and disease. Annu Rev Neurosci 35:369-389. CrossRef Medline

Stucky CL, Koltzenburg M, Schneider M, Engle MG, Albers KM, Davis BM 
(1999) Overexpression of nerve growth factor in skin selectively affects the survival and functional properties of nociceptors. J Neurosci 19: 8509-8516. Medline

Ting E, Guerrero AT, Cunha TM, Verri WA Jr, Taylor SM, Woodruff TM, Cunha FQ, Ferreira SH (2008) Role of complement C5a in mechanical inflammatory hypernociception: potential use of C5a receptor antagonists to control inflammatory pain. Br J Pharmacol 153:1043-1053. CrossRef Medline

Tordjmann T, Berthon B, Jacquemin E, Clair C, Stelly N, Guillon G, Claret M, Combettes L (1998) Receptor-oriented intercellular calcium waves evoked by vasopressin in rat hepatocytes. EMBO J 17:4695-4703. CrossRef Medline

Tschernig T, Kiafard Z, Dibbert C, Neumann D, Zwirner J (2007) Use of monoclonal antibodies to assess expression of anaphylatoxin receptors in rat and murine models of lung inflammation. Exp Toxicol Pathol 58: 419-425. CrossRef Medline

Twining CM, Sloane EM, Schoeniger DK, Milligan ED, Martin D, Marsh H, Maier SF, Watkins LR (2005) Activation of the spinal cord complement cascade might contribute to mechanical allodynia induced by three animal models of spinal sensitization. J Pain 6:174-183. CrossRef Medline

Underwood GA, Riches DW (1992) Transmembrane-mediated changes in $\left[\mathrm{Ca}^{2+}\right]$ are involved in the signaling pathway leading to macrophage cytocidal differentiation: implications of localized changes in intracellular $\left[\mathrm{Ca}^{2+}\right]$ and of interferon priming on $\mathrm{Ca}^{2+}$ utilization. Mol Biol Cell 3:335-347. CrossRef Medline

Vardanyan A, Wang R, Vanderah TW, Ossipov MH, Lai J, Porreca F, King T (2009) TRPV1 receptor in expression of opioid-induced hyperalgesia. J Pain 10:243-252. CrossRef Medline

Veerhuis R, Nielsen HM, Tenner AJ (2011) Complement in the brain. Mol Immunol 48:1592-1603. CrossRef Medline

Vega-Avelaira D, Géranton SM, Fitzgerald M (2009) Differential regulation of immune responses and macrophage/neuron interactions in the dorsal root ganglion in young and adult rats following nerve injury. Mol Pain 5:70. CrossRef Medline

Wagner E, Frank MM (2010) Therapeutic potential of complement modulation. Nat Rev Drug Discov 9:43-56. CrossRef Medline

Wang J, Hancock MK, Dudek JM, Bi K (2008) Cellular assays for highthroughput screening for modulators of Trk receptor tyrosine kinases. Curr Chem Genomics 1:27-33. CrossRef Medline

Wang NK, Lai CC, Liu CH, Yeh LK, Chou CL, Kong J, Nagasaki T, Tsang SH, Chien CL (2013) Origin of fundus hyperautofluorescent spots and their role in retinal degeneration in a mouse model of Goldmann-Favre syndrome. Dis Model Mech 6:1113-1122. CrossRef Medline
Wang Q, Rozelle AL, Lepus CM, Scanzello CR, Song JJ, Larsen DM, Crish JF, Bebek G, Ritter SY, Lindstrom TM, Hwang I, Wong HH, Punzi L, Encarnacion A, Shamloo M, Goodman SB, Wyss-Coray T, Goldring SR, Banda NK, Thurman JM, et al. (2011) Identification of a central role for complement in osteoarthritis. Nat Med 17:1674-1679. CrossRef Medline

Wang Z, Liu B, Wang P, Dong X, Fernandez-Hernando C, Li Z, Hla T, Claffey K, Smith JD, Wu D (2008) Phospholipase C beta3 deficiency leads to macrophage hypersensitivity to apoptotic induction and reduction of atherosclerosis in mice. J Clin Invest 118:195-204. CrossRef Medline

White FA, Jung H, Miller RJ (2007) Chemokines and the pathophysiology of neuropathic pain. Proc Natl Acad Sci U S A 104:20151-20158. CrossRef Medline

Wild KD, Bian D, Zhu D, Davis J, Bannon AW, Zhang TJ, Louis JC (2007) Antibodies to nerve growth factor reverse established tactile allodynia in rodent models of neuropathic pain without tolerance. J Pharmacol Exp Ther 322:282-287. CrossRef Medline

Woodruff TM, Strachan AJ, Dryburgh N, Shiels IA, Reid RC, Fairlie DP, Taylor SM (2002) Antiarthritic activity of an orally active C5a receptor antagonist against antigen-induced monarticular arthritis in the rat. Arthritis Rheum 46:2476-2485. CrossRef Medline

Woodruff TM, Crane JW, Proctor LM, Buller KM, Shek AB, de Vos K, Pollitt S, Williams HM, Shiels IA, Monk PN, Taylor SM (2006) Therapeutic activity of C5a receptor antagonists in a rat model of neurodegeneration. FASEB J 20:1407-1417. CrossRef Medline

Yamamoto S, Shimizu S, Kiyonaka S, Takahashi N, Wajima T, Hara Y, Negoro T, Hiroi T, Kiuchi Y, Okada T, Kaneko S, Lange I, Fleig A, Penner R, Nishi M, Takeshima H, Mori Y (2008) TRPM2-mediated Ca ${ }^{2+}$ influx induces chemokine production in monocytes that aggravates inflammatory neutrophil infiltration. Nat Med 14:738-747. CrossRef Medline

Yue X, Favot P, Dunn TL, Cassady AI, Hume DA (1993) Expression of mRNA encoding the macrophage colony-stimulating factor receptor (c-fms) is controlled by a constitutive promoter and tissue-specific transcription elongation. Mol Cell Biol 13:3191-3201. CrossRef Medline

Zhang N, Inan S, Cowan A, Sun R, Wang JM, Rogers TJ, Caterina M, Oppenheim JJ (2005a) A proinflammatory chemokine, CCL3, sensitizes the heat- and capsaicin-gated ion channel TRPV1. Proc Natl Acad Sci U S A 102:4536-4541. CrossRef Medline

Zhang X, Huang J, McNaughton PA (2005b) NGF rapidly increases membrane expression of TRPV1 heat-gated ion channels. EMBO J 24: 4211-4223. CrossRef Medline

Zhu W, Oxford GS (2007) Phosphoinositide-3-kinase and mitogen activated protein kinase signaling pathways mediate acute NGF sensitization of TRPV1. Mol Cell Neurosci 34:689-700. CrossRef Medline 